\title{
Heavy and light roles: myosin in the morphogenesis of the heart
}

\author{
Jennifer England · Siobhan Loughna
}

Received: 2 May 2012/Revised: 8 August 2012/ Accepted: 13 August 2012/Published online: 6 September 2012

(C) The Author(s) 2012. This article is published with open access at Springerlink.com

\begin{abstract}
Myosin is an essential component of cardiac muscle, from the onset of cardiogenesis through to the adult heart. Although traditionally known for its role in energy transduction and force development, recent studies suggest that both myosin heavy-chain and myosin lightchain proteins are required for a correctly formed heart. Myosins are structural proteins that are not only expressed from early stages of heart development, but when mutated in humans they may give rise to congenital heart defects. This review will discuss the roles of myosin, specifically with regards to the developing heart. The expression of each myosin protein will be described, and the effects that altering expression has on the heart in embryogenesis in different animal models will be discussed. The human molecular genetics of the myosins will also be reviewed.
\end{abstract}

Keywords Myosin - Myosin heavy chain .

Myosin light chain · Heart · Sarcomere .

Development $\cdot$ Congenital heart defects

\section{Introduction}

Congenital heart defects (CHDs) refer to anomalies in the structure of the heart or great vessels that are present at birth, and occur with a frequency of approximately $0.8 \%$ (one in 145 live births; British Heart Foundation http://www.bhf.org.uk). As CHDs account for nearly onethird of all major congenital defects, they are the most

J. England · S. Loughna $(\square)$

School of Biomedical Sciences, University of Nottingham,

Queens Medical Centre, Derby Road,

Nottingham NG7 2UH, UK

e-mail: siobhan.loughna@nottingham.ac.uk common defect in newborns [1]. The heart forms early in development, with a linear cardiac tube present in the midline of the embryo at day 22 in humans. This tube undergoes rapid morphological changes to give rise to a correctly aligned and septated four-chambered structure by the end of the seventh week of human embryogenesis. Several structural proteins that are expressed in the heart are now known to be essential for cardiogenesis. A number of the genes to these structural proteins give rise to CHDs upon mutation, with mutations in myosin heavy chain 6 the first to be associated in 2005 [2]. The myosin II hexameric molecule is composed of one pair of heavy chains and two pairs of light chains. Myosin heavy chain (MHC) proteins can be broadly classified into two groups; the sarcomeric (cardiac and skeletal) and nonsarcomeric (smooth muscle and nonmuscle) myosins. The myosin light-chain (MLC) proteins are also classed into two groups, the essential and regulatory light chains. This review will provide an overview of the roles the myosin proteins play in the developing heart and their potential to give rise to CHDs. The known molecular genetics in humans and animal models will be discussed.

\section{Myofibrillogenesis in the developing heart}

The heart is the first functional organ to develop in the vertebrate embryo due to the formation of myofibrils in cardiomyocytes that allow for muscle contraction. The sarcomere is the basic contractile unit of striated muscle, which is made of thick and thin filaments responsible for the generation of coordinated contractions. These sarcomeres unite to form individual myofibrils that align along the longitudinal axis of the rod-shaped cardiomyocytes. Myofibrils are highly ordered structures brought together 
by three components: actin and myosin filaments, accessory proteins of actin and myosin, and scaffolding proteins. A sarcomere spans between two Z-discs to which the thin filaments (actin-based) anchor and form the I-bands (Fig. 1). Myosin, the major component of the thick filament, is interdigitated between the actin-containing thin filaments creating A-bands in the center of the sarcomere. Thick filaments are held in place by an M-line, the central most structure of the sarcomere (Fig. 1). Titin is anchored to the Z-discs at its $\mathrm{N}$-terminus, and the M-line at its C-terminus, and is thought to be important for the assembly of the sarcomeric proteins [3] (Fig. 1). In cardiac muscle, myofibrils from individual cells are joined by intercalated discs, structures that are analogous to Z-discs that contain terminal ends of actin filaments of the sarcomere, but also act as an adherens junction between cardiomyocytes. These intercalated discs ensure mechanical coupling within the working myocardium $[4,5]$. Any impairment within the sarcomere can lead to dysfunction of the cardiac cells, and is therefore potentially detrimental to heart formation and function and hence to the embryo as it develops.

Myofibrillogenesis has become one of the most studied phenomena in development since structural proteins of the cardiac sarcomere were linked to myopathies (both cardiac and skeletal) and CHDs. Investigations into myofibrillogenesis have utilized the chicken heart as an animal model of the human heart. Contractions of the chicken heart initiate in the nine somite (HH10 or $36 \mathrm{~h}$ in ovo) embryo and just a few hours later, the cardiovascular system is so far developed that cardiomyocytes can pump blood throughout the embryo [6]. In fact, major components of the sarcomere are already expressed at the 6-somite (HH8) stage embryo prior to heart formation, where two regions of cardiogenic mesoderm containing premyocardial cells exist [7].
Therefore, myofibril assembly is an extremely rapid process that occurs early in development.

Myofibrillogenesis is a process containing a number of key steps including the formation of premyofibrils, nascent myofibrils, and mature myofibrils [8, 9]. Firstly, proteins assemble into structures known as premyofibrils, which resemble mini-sarcomeres (Fig. 2a). The first marker for the assembly of premyobrils is Z-bodies containing $\alpha$-actinin along the periphery of the cell [9]. Actin monomers are incorporated between these Z-bodies forming actin filaments until the myofibrils reach their mature stage [10]. In addition, at the stage of the premyofibril, nonmuscle myosin IIB is located distinctly between the $\alpha$-actinin containing Z-bodies (5-somite stage). Muscle myosin II is also present in these cells, and can even be detected before myofibrils begin to assemble (as early as the 3-somite stage), as rodlets of $0.76 \mu \mathrm{m}$. However, the muscle myosin remains scattered around the nucleus of the cardiomyocytes [8]. Secondly, the premyofibrils develop into nascent myofibrils that incorporate muscle-specific myosin II isoforms and stabilizing proteins (Fig. 2b). As nascent myofibrils develop, muscle myosin II begins to replace the nonmuscle isoform, and becomes distributed throughout the myofibril $(\sim 25 \mu \mathrm{m}$ in length). Titin is also expressed in the myofibril at this stage and is inserted into the Z-discs, thus playing its role in maintaining and organizing the structures of the sarcomere, including myosin integration [11, 12]. Finally, nascent myofibrils begin to fuse to one another to form mature myofibrils, which contain a highly organized structure of A-bands and Z-discs, composed of structural sarcomeric proteins (Fig. 2c) [8]. By the 9-somite stage (HH10), when the first cardiac contractions have occurred, muscle myosin II has replaced the nonmuscle myosin and appears as highly organized bi-polar filaments of $1.6 \mu \mathrm{m}$ in length $[8,13]$.
Fig. 1 Schematic representation of a sarcomere. The thick and thin filaments overlap in the region of the A-band, with the I-band formed from the thin filaments only. The central M-line anchors the thick filaments and the Z-disk the thin filaments. Titin is found along the length of the sarcomere. Tropomyosin and the troponin complex interact with actin to form part of the thin filament

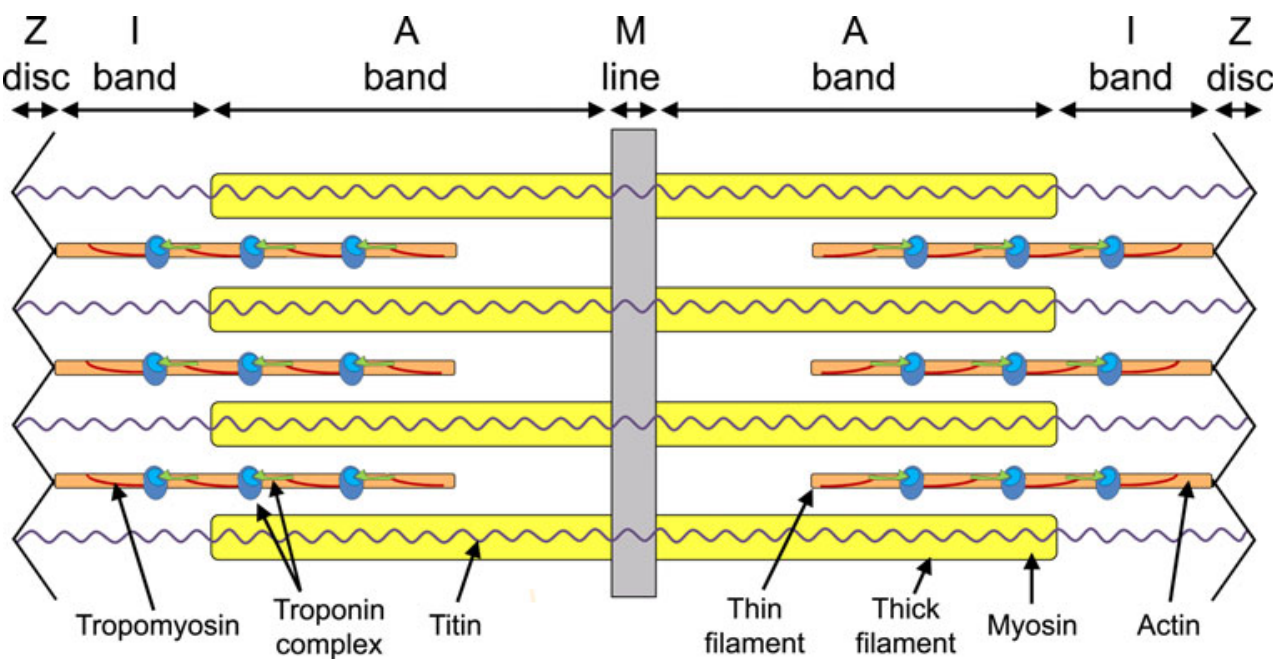




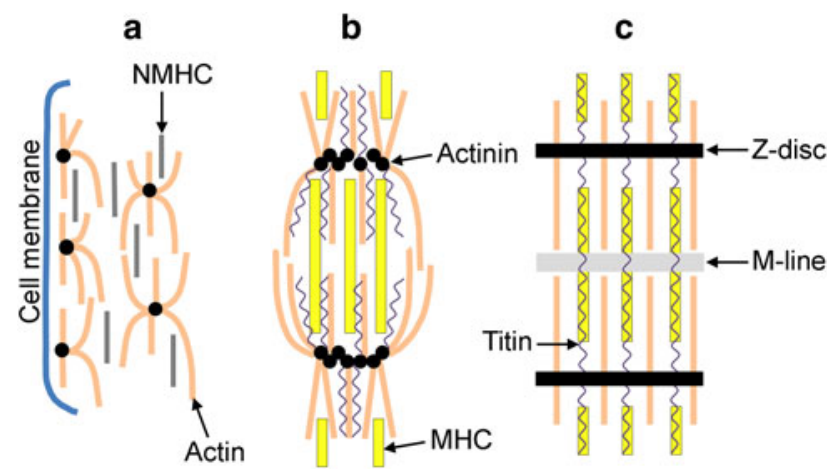

Fig. 2 The assembly of myofibrils. a Formation of premyofibrils. Proteins assemble into structures known as premyofibrils, which characteristically contain $\alpha$-actinin along the periphery of the cell, and nonmuscle myosin (NMHC) scattered between the actin. b Formation of nascent myofibrils. Muscle-specific myosin II isoforms and stabilizing proteins become incorporated into the myofibrils, with the myosin heavy-chain (MHC) proteins replacing NMHC. Titin is also expressed in the myofibril at this stage. c Formation of mature myofibrils. Nascent myofibrils fuse to form mature myofibrils, forming a highly organized sarcomeric structure

\section{Structure of the myosin molecule}

Myosin is a large, ubiquitous, motor protein that generates force through its interaction with actin, thus involving it in a number of cellular processes including cytokinesis, karyokinesis, cell migration, and muscle contraction [14]. Myosins can be divided into two distinct classes, the conventional two-headed myosins and the unconventional single-headed ones [15]. For the purpose of this review, we will be discussing the conventional class, which can be further subdivided into sarcomeric and nonsarcomeric myosins. The two-headed myosins are hexameric proteins (520 kDa) [14] comprising two myosin heavy-chain subunits and four myosin light-chain subunits (two regulatory and two essential light chains) [16]. The MHCs fold together at their $\mathrm{C}$-terminus, thus forming a dimerized coiled-coil $\alpha$-helix known as the tail region. This region contains the binding sites for myosin assembly into the sarcomere (e.g., titin and myosin-binding protein-C), and functions to anchor and position the motor domains of myosin so that it interacts with actin [17]. At the N-terminus, each MHC folds onto itself forming a globular head region (subfragment-1), so that each myosin molecule contains two globular heads. These head regions contain the binding sites for the MLCs, ATP, actin and divalent cations, and are called the motor region of the molecule (Fig. 3) [14].

The subfragment- 1 domain of a myosin molecule is asymmetrical and contains a MHC folded with two MLCs. The subfragment- 1 domain can be further subdivided into two regions; the motor domain and the regulatory domain,

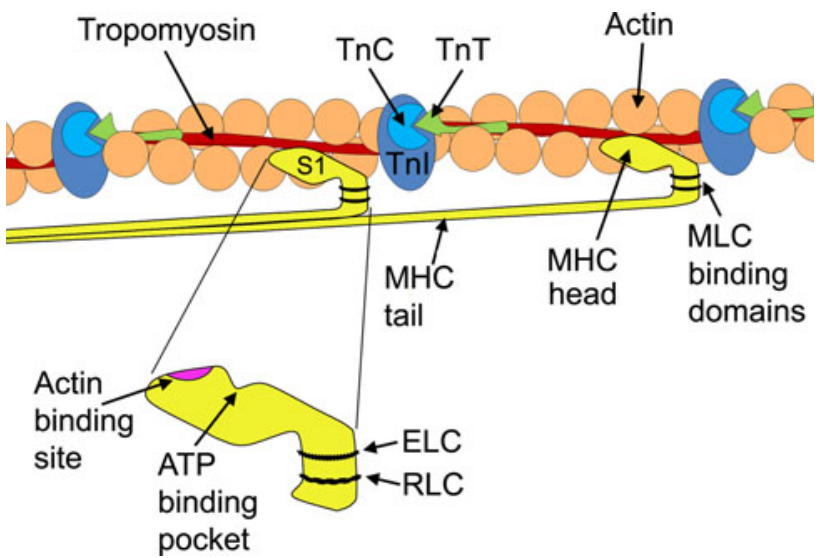

Fig. 3 Simplified view of the relationship between the globular head of myosin heavy chain and the thin filament. The positions of tropomyosin and $\mathrm{TnC}, \mathrm{TnI}$, and $\mathrm{TnT}$ along the actin filament are illustrated. A magnification of the globular head shows the position of the actin-binding site, the ATP pocket, and the essential light chain (ELC) and regulatory light chain (RLC) binding domains. $M H C$ myosin heavy chain, $M L C$ myosin light chain, $S 1$ subfragment-1, Tn troponin

which links the motor domain to the tail of the myosin molecule [18]. Proteolysis of the myosin head reveals three major segments; a $25-\mathrm{kDa} \mathrm{N}$-terminal portion, a central 50-kDa segment which together form the motor domain, and a $20-\mathrm{kDa} \mathrm{C}$-terminal region, containing the regulatory domain [19]. The 50-kDa segment is separated into an upper and lower subdomain by a long, narrow cleft containing an actin-binding site. The $25-\mathrm{kDa}$ segment attaches to the 50-kDa domain with an ATP-binding pocket located at the site of attachment. The $20-\mathrm{kDa}$ segment is the site to which one regulatory and one essential light chain bind. It is the most extended region, formed by a long $\alpha$-helix [18]. This region is thought to amplify small conformational changes into large movements needed to produce force, and therefore, sarcomeric contraction [20].

The MLCs are comprised of two sub-families, the essential or alkali MLC (MLC1 or ELC) and regulatory MLC (MLC2 or RLC), which have molecular masses of 22 and $19 \mathrm{kDa}$, respectively. The MLCs wrap around the $\alpha$-helical neck region (20-kDa region) of the MHC in an anti-parallel orientation and stabilize it. The arrangement of MLCs relative to the ATP-binding site and actin-binding sites of the motor domain suggests a function in creating a longer molecule to amplify power stroke [18]. MLCs belong to the EF-hand family, a large family of $\mathrm{Ca}^{2+}$-binding proteins also associated with calmodulin and troponin-C [21]. MLCs contain two $\mathrm{Ca}^{2+}$-binding EF-hand motifs and different isoforms of MLCs may modulate the $\mathrm{Ca}^{2+}$ sensitivity of force generation and cross-bridge kinetics (discussed below) [22]. A key difference between MLC2 and MLC1 is a serine residue of the MLC2, which 
MLC1 lacks, in the N-terminal of the peptide. MLC2 are regulated through $\mathrm{Ca}^{2+}$-mediated phosphorylation of this residue, which causes the MLC2 to undergo conformational changes from a compacted to an elongated form [23]. MLC1 on the other hand has a unique N-terminal that binds actin, thus contributing to the cross-bridge cycle kinetics, i.e., force production [24, 25].

\section{Myosin and the cross-bridge cycle}

Force generation and muscle contraction are produced by the cyclic interactions of the myosin head with actin filaments, which is fuelled by ATP and regulated by $\mathrm{Ca}^{2+}$. ATP controls the affinity that myosin has to actin during the cycle. The ATP-binding site on the myosin head binds ATP (Fig. 4a), which in turn hydrolyzes to produce ADP and an inorganic phosphate (Fig. 4b) [26]. This causes myosin to bind to actin (at the actin-binding site) via weak ionic interactions (Fig. 4c). It is at this point that $\mathrm{Ca}^{2+}$ regulates the interactions between the myosin head and the actin filament, thus initiating conformational changes in the head region of myosin. Isomerization of the subfragment-1 unit of myosin associated with the release of the inorganic phosphate and strong myosin-actin bonding, results in extension of the 20-kDa lever arm of the myosin molecule, allowing sliding of the two filaments (Fig. 4d) [27]. ADP is then released and ATP quickly rebinds to the nucleotide- binding region [28]. The myosin head therefore dissociates from the actin and the cycle is complete [29, 30].

$\mathrm{Ca}^{2+}$ regulates the cross-bridge cycle in striated muscle, via the movement of tropomyosin, allowing hydrophobic interactions to occur between myosin and actin resulting in a tighter bond between the two molecules [31]. Therefore, $\mathrm{Ca}^{2+}$ activates the cross-bridge cycle through the thin filament regulatory system. At low levels of $\mathrm{Ca}^{2+}$ within the sarcoplasm (cytoplasm of the muscle cell), $\mathrm{Ca}^{2+}$ is not bound to the calcium-specific binding sites of troponin $\mathrm{C}$ ( $\mathrm{TnC}$ ). $\mathrm{TnC}$ is weakly bound to $\mathrm{TnI}$ and $\mathrm{TnT}$, but $\mathrm{TnI}$ is strongly bound to actin, which holds tropomyosin in a position that blocks the myosin-binding sites on the actin filaments (i.e., the blocked state). When $\mathrm{Ca}^{2+}$ is released by the sarcoplasmic reticulum and intracellular concentrations of $\mathrm{Ca}^{2+}$ are increased, cross-bridge cycling is turned on. $\mathrm{Ca}^{2+}$ binds to $\mathrm{TnC}$ inducing a conformational change of the troponin complex [32]. The strength of the interaction between $\mathrm{TnC}$ and $\mathrm{TnI}$ increases, weakening the interaction between $\mathrm{TnT}$ and tropomyosin, $\mathrm{TnI}$ and tropomyosin, and $\mathrm{TnI}$ and actin. This results in TnI being pulled away from the actin filaments. This causes a $30^{\circ}$ shift in the tropomyosin molecule around the thin filament, thus exposing myosin-binding sites that it once covered on the actin filaments (Fig. 4c) [33]. Actin interacts with myosin in a stereospecific manner (the closed state). As $\mathrm{Ca}^{2+}$ continuously increases, the transition from a weak to strong cross-bridging pushes the tropomyosin further from its

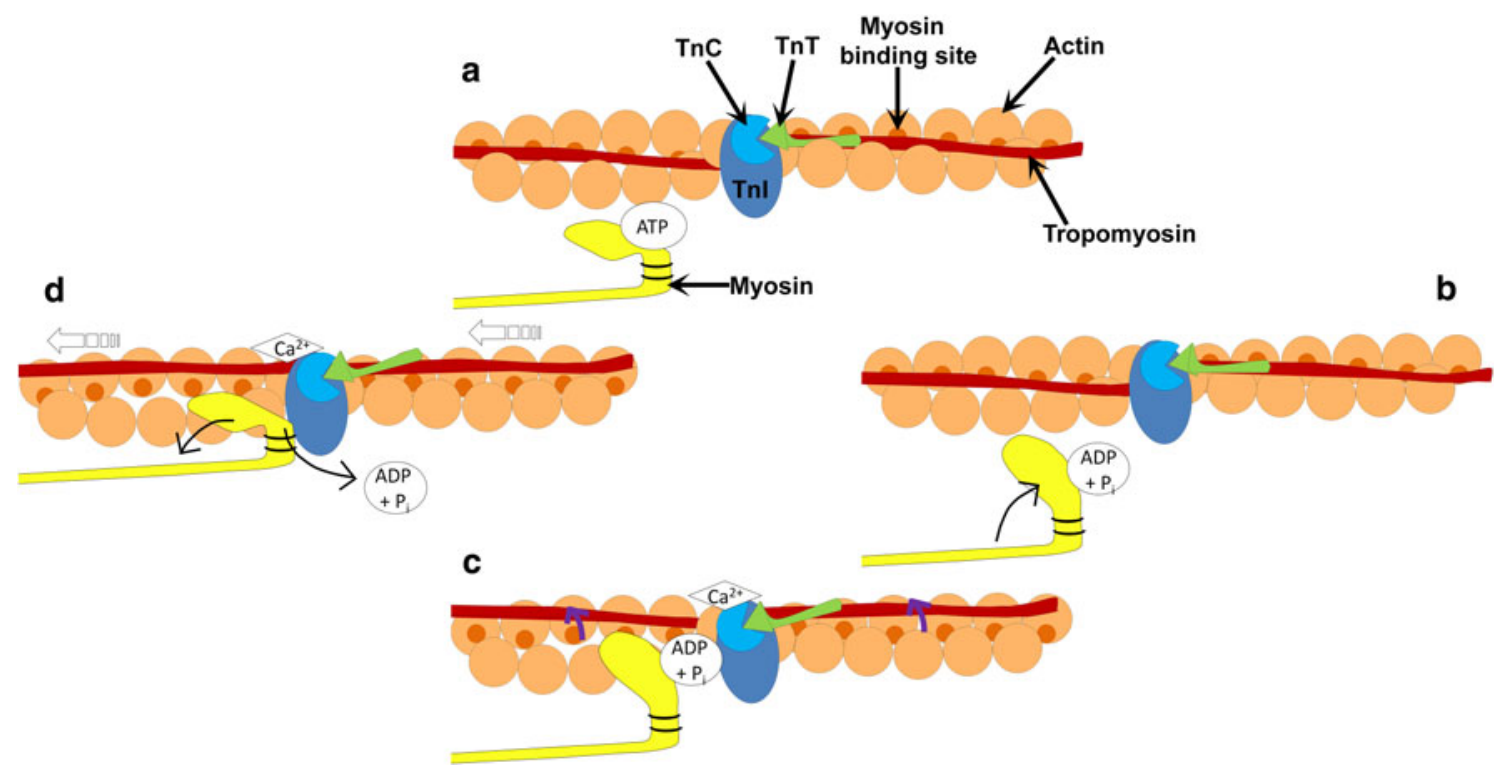

Fig. 4 Schematic diagram of the cross-bridge cycle. a ATP binds to the ATP-binding domain on the myosin head. b ATP is hydrolyzed to ADP and a phosphate allowing the myosin head to move towards the actin filament. c Binding of $\mathrm{Ca}^{2+}$ to troponin $\mathrm{C}(\mathrm{TnC})$ results in a conformational change in the troponin complex, allowing the movement of tropomyosin around the actin filament (as indicated by the purple arrows). $\mathbf{d}$ Release of the hydrolyzed nucleotides results in the extension of the myosin head permitting the sliding of the filaments (open arrows). ATP quickly rebinds to the ATP-binding site on the myosin head, allowing dissociation of the myosin away from the actin filament, and the cycle is repeated 
closed position on the actin filament and allows for the complete uncovering of myosin-binding sites and leads to power stroke and generation of force and movement [34]. Figure 3 shows the relationship myosin has to actin, the troponin complex, and tropomyosin.

Phosphorylation of MLC2, via $\mathrm{Ca}^{2+} /$ calmodulindependent myosin light-chain kinases, increases the mobility of myosin cross-bridges such that the myosin heads move away from the thick filament towards actin thin filaments in striated muscle fibers [35]. MLC2 phosphorylation increases the number of cross-bridges entering the contractile cycle by upregulation of the actin-induced phosphate release from the weakly bound actin-myosin ADP-P state. This leads to an increase in $\mathrm{Ca}^{2+}$ sensitivity of the myofilament and increases the rate of force development by increasing cross-bridge transition to the strongly bound, force-generating state, while slowing the rate of decay of the force-generating state [36]. In smooth muscle and nonmuscle myosins, $\mathrm{Ca}^{2+}$ release is a major determinant of contraction, by activating the $\mathrm{Ca}^{2+} /$ calmodulindependent protein kinases that phosphorylate MLC2 [37]. This phosphorylation increases myosin ATPase activity, resulting in cross-bridge cycling [38]. For detailed reviews on this area, see [39-41].

\section{The myosin heavy-chain genes}

The nomenclature for the myosin II proteins has varied within the literature. For the purposes of this review, the genes have been named according to the nomenclature described by the HUGO gene nomenclature committee (http://www.genenames.org). However, as the myosin proteins are found as hexameric molecules, it was deemed inappropriate to name using the same terminology as the gene. Therefore, the protein has been named using traditional terminology. To avoid confusion, but to also be consistent with the literature, myosin heavy chain is abbreviated to MYH when used to name genes and MHC to name protein product.

Thirteen genes have been described for mammalian MYH including nine sarcomeric muscle genes, three nonmuscle genes, and one smooth muscle gene. Of the sarcomeric muscle genes, six skeletal MYH genes (MYH1, MYH2, MYH3, MYH4, MYH8, and MYH13) are grouped together on human chromosome $17 \mathrm{p}$. The three other striated muscle genes are cardiac MYH genes, MYH6 and MYH7 (located on chromosome 14q11.2-q13) and $M Y H 7 B$ (chromosome 20q11). There are three nonmuscle myosin II isoforms in humans; MYH9 (chromosome 22q11.2), MYH1O (chromosome 17p13) and MYH14 (chromosome 19q13.33). The smooth muscle gene is MYH11 (chromosome 16p13.11).
As will be reviewed below, the MYH genes that are expressed to the heart in development are the sarcomeric myosins $M Y H 3, M Y H 6, M Y H 7$, and $M Y H 7 B$ and the nonsarcomeric nonmuscle myosins $M Y H 9$, MYH10, and MYH14. The smooth muscle myosin MYH11 is absent to the heart but present to parts of the vasculature including the aorta. Although these genes are all expressed to the heart or great vessels, clear roles for all in developmental processes within the human cardiovascular system have yet to be fully elucidated. However, model organisms have provided interesting insights into functional roles for many of these genes, which will be discussed below.

The protein product from the $M Y H 3$ gene is named as embryonic myosin heavy chain (eMHC) and MYH6 is called alpha myosin heavy chain $(\alpha M H C)$ in this review though sometimes as atrial myosin heavy chain (atrial MHC) within the literature. The $M Y H 7$ product is referred to as beta myosin heavy chain $(\beta \mathrm{MHC})$ in this review though ventricular myosin heavy chain (ventricular MHC) has also been used. Finally, the nonmuscle myosin $M Y H 9$ is referred to as NMHC IIA, MYH10 is termed NMHC IIB and $\mathrm{MYH14}$ is called NMHC IIC. The smooth muscle myosin $\mathrm{MYH1} 1$ product is usually named smooth muscle myosin heavy chain (SM-MHC) within the literature and has been used in this review. For a summary of gene names, human chromosomal location and protein name, see Table 1.

\section{The myosin heavy chains and the cardiovascular system}

Each myosin heavy-chain gene, which plays a role, or potential role, in heart development is reviewed and the expression and function each gene plays in the heart is described for different animal models. Table 2 summarizes the known effects of altered gene expression during cardiogenesis. $\alpha \mathrm{MHC}$ is extensively homologous across species and Fig. 5 illustrate this between the human and the chick, with many important functional domains showing $100 \%$ homology. This degree of conservation across species shows the importance of the MHC proteins.

Myosin heavy chain 3

eMHC is a skeletal myosin heavy chain protein. $M Y H 3$ transcripts are expressed in human fetal skeletal muscle predominately, although they are also expressed by adult skeletal muscle [42]. Roles for $M Y H 3$ have yet to be shown in the human heart, although expression has been seen by in situ hybridization in human 4-, 5.5-, and 7-week fetal hearts, with RNA localized in the myocardium of the atrium, ventricle, and sinus venosus [42]. The chick $M Y H 3$ gene is expressed in the myotome, skeletal muscle, and 
Table 1 Chromosomal location and nomenclature of myosin II

\begin{tabular}{|c|c|c|}
\hline $\begin{array}{l}\text { Gene } \\
\text { name }\end{array}$ & $\begin{array}{l}\text { Human chromosomal } \\
\text { location }\end{array}$ & Commonly used protein name \\
\hline МYH3 & 17 pter-p11 & $\begin{array}{l}\text { Embryonic myosin heavy chain } \\
\text { (eMHC) }\end{array}$ \\
\hline МYH6 & $14 q 11.2-q 13$ & $\begin{array}{l}\text { Alpha myosin heavy chain } \\
(\alpha \mathrm{MHC}) \\
\text { Atrial myosin heavy chain (atrial } \\
\text { MHC) }\end{array}$ \\
\hline MYH7 & $14 q 11.2-q 13$ & $\begin{array}{l}\text { Beta myosin heavy chain ( } \beta \text { MHC) } \\
\text { Ventricular myosin heavy chain } \\
\text { (ventricular MHC) }\end{array}$ \\
\hline$M Y H 7 B$ & $20 \mathrm{q} 11$ & Myosin heavy chain 7B \\
\hline МYH9 & $22 \mathrm{q} 11.2$ & $\begin{array}{l}\text { Nonmuscle myosin heavy chain } \\
\text { IIA (NMHC IIA) }\end{array}$ \\
\hline МYH1O & $17 \mathrm{p} 13$ & $\begin{array}{l}\text { Nonmuscle myosin heavy chain } \\
\text { IIB (NMHC IIB) }\end{array}$ \\
\hline МYH11 & $16 \mathrm{p} 13.11$ & $\begin{array}{l}\text { Smooth muscle myosin heavy } \\
\text { chain (SM-MHC) }\end{array}$ \\
\hline MYH14 & $19 q 13.33$ & $\begin{array}{l}\text { Nonmuscle myosin heavy chain } \\
\text { IIC (NMHC IIC) }\end{array}$ \\
\hline MYL2 & $12 \mathrm{q} 24.11$ & $\begin{array}{l}\text { Myosin light chain } 2 \text { ventricular } \\
(\text { MLC2v) } \\
\text { Regulatory light chain ventricular } \\
\text { (RLCv) }\end{array}$ \\
\hline MYL3 & $3 \mathrm{p} 21.3-21.2$ & $\begin{array}{l}\text { Myosin light chain } 1 \text { ventricular } \\
\quad(\text { MLC1v) } \\
\text { Essential light chain ventricular } \\
\text { (ELCv) }\end{array}$ \\
\hline MYL4 & $17 \mathrm{q} 21.32$ & $\begin{array}{l}\text { Myosin light chain } 1 \text { atrial } \\
\quad \text { (MLC1a) } \\
\text { Essential light chain atrial (ELCa) } \\
\text { Embryonic myosin light chain }\end{array}$ \\
\hline MYL7 & $12 \mathrm{q} 13.2$ & $\begin{array}{l}\text { Myosin light chain } 2 \text { atrial } \\
\text { (MLC2a) } \\
\text { Regulatory light chain atrial } \\
\text { (RLCa) }\end{array}$ \\
\hline
\end{tabular}

Only myosin heavy chains and myosin light chains that are expressed in the heart are listed

The gene name is the approved nomenclature according to HUGO (http://www.genenames.org)

chick heart from HH12 (an early stage of cardiac looping) through to the adult heart [42-45]. In the chick, eMHC staining was detected in the myocardium of the atrial, ventricular, and outflow regions of the developing heart [42]. In addition, immunoreactivity at $\mathrm{HH} 9$ was detected in a heart-specific manner, demonstrating this structural protein is expressed from the earliest stages of cardiogenesis.

Mutations in human MYH3 have been associated with Freeman-Sheldon and Sheldon-Hall syndromes, both syndromes associated with skeletal defects [46, 47]; defects to the heart were not described. However, upon knockdown of eMHC during early cardiogenesis in the chick, the atrial septa and trabeculae developed abnormally [42]. Further, both atrial and ventricular cardiomyocytes formed an abnormal action potential (AP) and had decreased intracellular $\mathrm{K}^{+}$and $\mathrm{Ca}^{2+}$ transient spikes. With regards to the ventricular cells, most were electrically inactive. These data suggest that the structural protein $\mathrm{MHC}$ is a candidate gene for atrial septal defects (ASD; an abnormal opening between the left and right atria chambers) and conduction anomalies [42]. Analysis of $M Y H 3$ has not been performed in any other animal models to our knowledge.

Myosin heavy chain 6

The expression profile of $\alpha \mathrm{MHC}$ protein is similar in the chick and human, both during development and postnatally. Expression is observed in skeletal muscle and the heart during development and in the adult. During cardiac development, although expression is found to be higher in the atria, expression is seen in the ventricles, with the ventricular expression decreasing relative to the atria as development progresses [48-51]. In the adult heart, $\alpha \mathrm{MHC}$ is predominately expressed in the atrium with very low levels found in the ventricles [48-50]. In rodents, however, although Myh6 is predominantly expressed to the atrial region during embryogenesis, a presence is also demonstrated in the ventricle, and Myh6 becomes the dominant myosin heavy-chain isoform after birth in both the atrial and ventricular chambers $[50,52]$. The orthologue to MYH6 in zebrafish is atrial MYH, which is atrial-specific during embryogenesis (zebrafish form a two-chambered heart) [53]. In Xenopus (which forms a three-chambered heart with two atria and one ventricle), the orthologue to MYH6 is also called atrial MYH. Atrial MYH is the dominant myosin heavy-chain gene during early frog cardiogenesis, with expression throughout the myocardium [54]. Expression is also throughout the heart of the adult frog.

Despite intensive screening, relatively few mutations have been found in the MYH6 gene that have been linked to cardiomyopathy [55-57], suggesting low penetrance of this phenotype compared to genes such as $M Y H 7$ (see below). With regards to a role in the developing heart, $\alpha \mathrm{MHC}$ was the first structural protein that upon mutation of its gene was associated with a CHD, with members of a family carrying a MYH6 mutation afflicted with an ASD [2]. This mutation caused a hydrophobic isoleucine to change to a hydrophilic asparagine (I820N). This missense mutation $(18,429 \mathrm{~T}>\mathrm{A})$ was in the neck region and was predicted to affect the binding of the myosin heavy chain to its regulatory light chain. Subsequently, a number of missense mutations, a splice site and a nonsense mutation have been found in MYH6 [58, 59]. Defects were not exclusive to ASDs, with a number of other CHDs found including other 
Table 2 Genes encoding myosin structural proteins associated with the developing heart

\begin{tabular}{|c|c|c|c|c|}
\hline Gene & Species & Mutation/effect on gene expression & CHDs associated with mutation/developmental process & References \\
\hline MYH3 & Chick & Knockdown & $\begin{array}{l}\mathrm{Ab} \text { atrial and trabeculae development; enlarged heart; } \\
\text { abnormal AP and calcium and potassium transients }\end{array}$ & [42] \\
\hline \multirow[t]{20}{*}{ MYH6 } & \multirow[t]{13}{*}{ Human } & $\mathrm{I} 820 \mathrm{~N}$ & ASD & {$[2]$} \\
\hline & & $\mathrm{A} 230 \mathrm{P}$ & TA & \multirow[t]{7}{*}[58]{} \\
\hline & & H252Q & TGA, PFO & \\
\hline & & E501Stop & TA & \\
\hline & & V700M & $\mathrm{PFO}$ & \\
\hline & & A1366D & AS, SDK, SAR, PFO & \\
\hline & & A1443D & ASD & \\
\hline & & R1865Q & ASD, DIVC, VSD & \\
\hline & & IVS37-2A $>$ G & ASD, PTA & \multirow[t]{5}{*}[59]{} \\
\hline & & $\mathrm{R} 17 \mathrm{H}$ & ASD, AVSD, SVC/CS & \\
\hline & & C539R & ASD & \\
\hline & & K543R & ASD & \\
\hline & & A1004S & ASD & \\
\hline & \multirow[t]{3}{*}{ Chick } & \multirow[t]{3}{*}{ Knockdown } & Ab atrial septal development & {$[2,61]$} \\
\hline & & & $\mathrm{Ab}$ trabeculae development; looping defects, $\mathrm{EH}$ & {$[61]$} \\
\hline & & & $\mathrm{Ab}$ calcium transients in atrium & [42] \\
\hline & \multirow[t]{2}{*}{ Mouse } & Homozygous & Death E11-12.5, heart phenotype ND & {$[60]$} \\
\hline & & Heterozygote & Viable, fertile, Ab cardiac function, fibrotic lesions, Ab sarcomeres & {$[60]$} \\
\hline & Zebrafish & Weak atrium homozygous & Absent contraction, Ab myofibrillogenesis in atrium & {$[53]$} \\
\hline & Xenopus & Muzak homozygous & Absent myofibrils and cardiac contraction, EH & {$[62]$} \\
\hline \multirow[t]{12}{*}{ MYH7 } & \multirow[t]{8}{*}{ Human } & $\mathrm{R} 281 \mathrm{~T}$ & ASD, EA & {$[65]$} \\
\hline & & Y283D & ASD, VSD, pulAH & \multirow[t]{7}{*}[66]{} \\
\hline & & Y350N & EA & \\
\hline & & L390P & EA, PFO & \\
\hline & & K1459N & EA & \\
\hline & & N1918K & $\mathrm{Coa} / \mathrm{BAV}$ & \\
\hline & & E1573K & VSD & \\
\hline & & 1220delE & EA & \\
\hline & \multirow[t]{2}{*}{ Chick } & \multirow[t]{2}{*}{ Knockdown } & $\mathrm{Ab}$ calcium transients in atrium and ventricle & [42] \\
\hline & & & $\mathrm{EH}$ & UnD \\
\hline & Zebrafish & Half-hearted & Enlarged ventricle, fewer myofibrils, increased cardiomyocytes & {$[70]$} \\
\hline & Medaka fish & Hozuki mutant & Enlarged ventricle, increased cardiomyocytes & [71] \\
\hline МYH10 & Mouse & Homozygous & VSD, DORV, hypertrophic cardiac myocytes & {$[78]$} \\
\hline \multirow[t]{9}{*}{ MYHI1 } & \multirow[t]{8}{*}{ Human } & IVS32 $+1 \mathrm{G}$ to $\mathrm{T}$ & TAAD & {$[82]$} \\
\hline & & R1758Q & & \\
\hline & & R1241_L1264del & & \\
\hline & & L1264P & TAAD, PDA & {$[83]$} \\
\hline & & $\mathrm{R} 1275 \mathrm{~L}$ & & \\
\hline & & R712Q & & \\
\hline & & R669C & PDA & {$[84]$} \\
\hline & & E1290Q & & \\
\hline & Mouse & Homozygous & PDA & {$[85]$} \\
\hline \multirow[t]{2}{*}{ MYL2 } & Mouse & Homozygous null & Death E12.5, EH, wall thinning, Ab sarcomeres & [97] \\
\hline & Chick & Knockdown & $\mathrm{Ab}$ cardiac looping, $\mathrm{Ab}$ sarcomeres & [91] \\
\hline MYLA & Zebrafish & Knockdown & Ab sarcomeres with increased length, decreased contractility & {$[110]$} \\
\hline
\end{tabular}


Table 2 continued

\begin{tabular}{|c|c|c|c|c|}
\hline Gene & Species & Mutation/effect on gene expression & CHDs associated with mutation/developmental process & References \\
\hline \multirow[t]{3}{*}{$M Y L 7$} & Mouse & Homozygous null & $\begin{array}{l}\text { Death E10.5-11.5, EH tube, Ab looping, Ab trabeculae, } \\
\text { left ventricular dilation, Ab myofibril assembly }\end{array}$ & [121] \\
\hline & Zebrafish & Knockdown & $\mathrm{Ab}$ sarcomeres with decreased length and contractility, EH & {$[110]$} \\
\hline & & Tell tale homozygous & $\mathrm{Ab}$ contraction, $\mathrm{Ab}$ sarcomeres & [120] \\
\hline
\end{tabular}

Only mutations and phenotypes related to cardiac development are described; mutations and phenotypes related to cardiac function e.g., cardiomyopathy, are not listed

$A b$ abnormal, $A P$ action potential, $A S$ aortic stenosis, $A S D$ atrial septal defect, $A V S D$ atrioventricular septal defect, $B A V$ bicuspid aortic valve, Coa coarctation of the aorta, DIVC dilated inferior vena cava, DORV double outlet right ventricle, $E$ embryonic day, $E A$ Epstein's anomaly, $E H$ enlarged heart, $N D$ not determined, $P D A$ patent ductus arteriosus, $P F O$ persistence of foramen ovale, $P T A$ persistent truncus arteriosus, $P$ ulAH pulmonary artery hypoplasia, $S A R$ subaortic ridge, $S D K$ septal dyskinesis, $T A$ tricuspid atresia, $S V C / C S$ abnormal drainage of superior vena cava to coronary sinus, TAAD thoracic aortic aneurysm and/or aortic dissection, $T G A$ transposition of the great arteries, UnD unpublished data (Dr. CS Rutland and SL), VSD ventricular septal defect

septal anomalies ventricular septal defect (VSD; an abnormal opening between the left and right ventricular chambers) and persistent truncus arteriosus (PTA; the septum between the pulmonary trunk and aorta fails to form). Functional analysis of three of the missense mutations suggests that these mutations affect the normal formation of the myofibrils, with A230P and A1366D disrupting and $\mathrm{H} 252 \mathrm{Q}$ enhancing assembly [58]. The location of all these missense mutations are denoted on the $\alpha \mathrm{MHC}$ protein in Fig. 5.

A number of animal models have provided a greater understanding of this gene. In the mouse null mutant, loss of Myh6 led to embryonic lethality, with death occurring at embryonic day (E) 11-12.5 [60]. However, the embryonic heart phenotype was not characterized. In the heterozygote animals, mice were found to be viable and fertile with no overt phenotype. Upon detailed cardiac function studies, however, adult heterozygotes (12-25 weeks post-birth) had defects in cardiac contraction and relaxation with incomplete penetrance, in comparison to wild-types [60]. Further, histological analysis revealed fibrotic lesions in heterozygote mice. In the chick, knockdown of $\alpha \mathrm{MHC}$ has demonstrated roles for this structural protein in the initiation and/or maintenance of the atrial septum [2, 61]. Further, development of the ventricular trabeculae and the structural architecture of the atrial septum, was on occasion found to be aberrant [61]. In addition, at a low penetrance, abnormal cardiac looping and an enlarged heart were observed. Individual atrial and ventricular cardiomyocytes from HH19 knockdown hearts had normal AP characteristics, although cytosolic $\mathrm{Ca}^{2+}$ appeared to show modest changes in atrial (but not ventricular) cells compared to controls [42]. These data suggest that $\alpha \mathrm{MHC}$ may not play a critical role in the conduction system early in development. A loss-of-function mutation of the myh6 gene in zebrafish, called weak atrium, is due to a frameshift mutation with the loss of thymidine at position 4,024 [53]. Loss of myh6 in zebrafish caused absent atrial contraction and abnormal myofibrillogenesis, with secondary defects consisting of thickening of myocardial wall and a decrease in ventricular lumen size [53]. Despite these defects, homozygous weak atrium mutants can survive to adulthood and heterozygotes appeared normal [53]. A nonsense mutation (a C to T transition at position 3,187 ) of myh6 in Xenopus tropicalis, the muzak mutant, resulted in deletion of the coiled-coil domain [62]. These mutants have absent myofibrils and the heart fails to contract, which led to a number of presumed secondary effects including absent trabeculae and cardiac valves. Heterozygotes had no discernible phenotype [62].

\section{Myosin heavy chain 7}

MYH7 is considered to be the ventricular myosin heavychain gene. The $\beta \mathrm{MHC}$ protein is expressed mainly in the ventricle in both the fetal (from 47 days, the earliest stage analyzed) and adult human heart [48, 49]. During embryogenesis in rodents, expression of $M y h 7$ also becomes ventricular-specific, seen from E7.5 in the mouse $[50,52]$. In addition, in contrast to other species, expression of $M y h 7$ is downregulated postnatally in rodents, so that in the adult heart Myh6 is the dominant myosin heavychain gene expressed in both the atrial and ventricular chambers [50, 52]. Outside the heart, $\beta \mathrm{MHC}$ is also expressed in skeletal muscle during development and in the adult. The expression profile of $M Y H 7$ in the chick is similar to that in humans [48-51]. The presumptive functional orthologue to MYH7 in Xenopus is not expressed in the frog heart prior to chamber formation; subsequently from stage 45 expression is seen in the regions between the ventricle and outflow tract, and between the ventricle and atria [54]. Ventricular- and outflow-specific expression is seen in the adult frog. Ventricular-specific expression of 


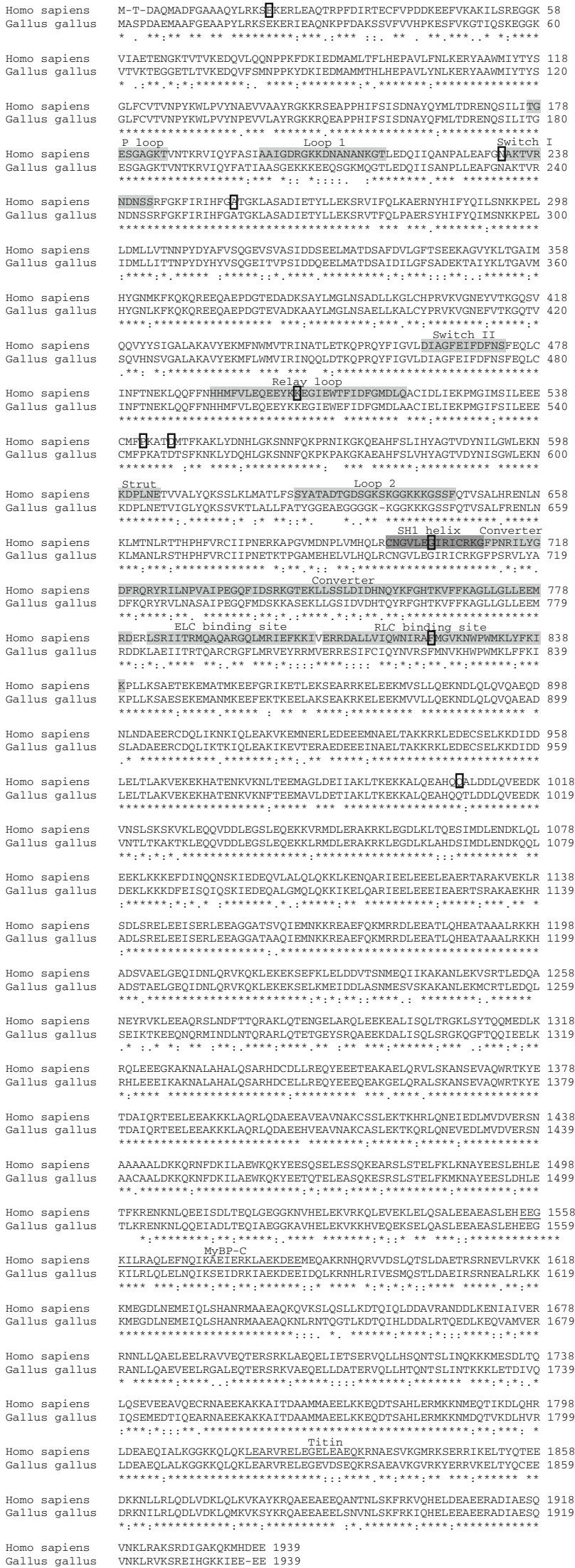
WASPDAEMAAFGEAAPYLRKSEKERIEAQNKPFDAKSSVFVVHPKESFVKGTIQSKEGGK 60 VIAETENGKTVTVKEDQVLQQNPPKFDKIEDMAMLTFLHEPAVLFNLKERYAAWMIYTYS 11 VTVKTEGGETLTVKEDQVFSMINP PKYDKIEDMAMMTHLHEPAVLYNLKERYAAWMIYTYS 120 GLFCVTVNPYKWLPVYNAEVVAAYRGKKRSEAPPHIFSISDNAYQYMLTDRENQSILITG 178 GLFCVTVNPYKWLPVYNPEVVLAYRGKKRQEAPPHIFSISDNAYQFMLTDRENQSILITG 180

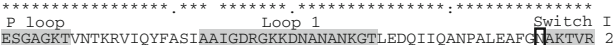
ESGAGKTVNTKRVIQYFATIAASGEKKKEEQSGKMQGTLEDQIISANPLLEAFGNAKTVR 240 NDNSSRFGKFIRIHFG 1 TTGKLASADIETYLLEKSRVIFQLKAERNYHIFYQILSNKKPEL 298

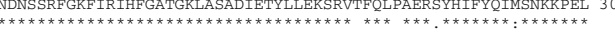
LDMLLVTNNPYDYAFVSOGEVSVASIDDSEELMATDSAFDVLGFTSEEKAGVYKLTGAIM 358

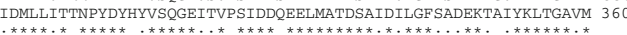
HYGNMKFKQKQREEQAEPDGTEDADKSAYLMGLNSADLLKGLCHPRVKVGNEYVTKGQSV 418

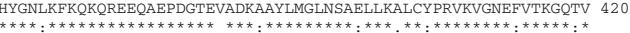
QQVYYSIGALAKAVYEKMFNWMVTRINATLETKQPRQYFIGVLDIAGFETFDFNSFEQLC 478 SQVHNSVGALAKAVYEKMFLWMVIRINQQLDTKQPRQYFIGVLDIAGFEIFDFNSFEQLC 480

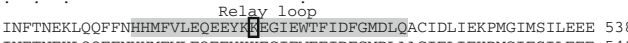
INFTNERLQQFFNHHMFVLEQEEYKKEGIEWEF IDFGMDLAACIELIEKPMGIFSILEEE 540 CMFGKAT MTFKAKLYDNHLGKSNNFOKPRNIKGKOEAHFSLIHYAGTVDYNILGWLEKN 598 CMFPKATDTSFRNKLYDQHLGKSNNFQKPKPAKGRAEAHFSLVHYAGVDYNISGWLEKN 600

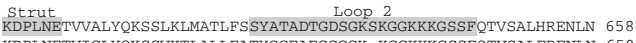
KDPLNETVIGLYQKSSVKTLALLFATYGGEAEGGGGK-KGGKKKGSSFQTVSALFRENLN 659

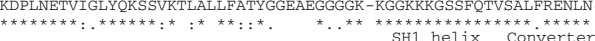

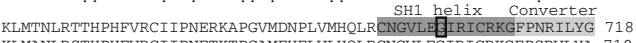

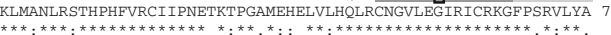
DFRQRYRILNPVAIPEGQFIDSRKGTEKLLSSLDIDHNQYKFGHTKVFFKAGLLGLLEEM 77

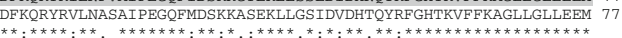
ELC binding site
RDERLSRIITRMQAQARGQLMRIEFKKIVERRDALIVIC bind ing site RDDKLAEIITRTQARCRGFLMRVEYRRMVERRESIFCIQYNVRSFMNVKHWPWMKLFFKI 839 KPLLKSAETEKEMATMKEEFGRIKETLEKSEARRKELEEKMVSLLQEKNDLQLQVQAEQD 898 KPLLKSAESEKEMANMKEEFEKTKEELAKSEAKRKELEEKMVVLLQEKNDLQLQVQAEAD 899 NLNDAEERCDQLIKNKIQLEAKVKEMNERLEDEEEMNAELTAKKRKLEDECSELKKDIDD 958 SLADAEERCDQLIKTKIQLEAKIKEVTERAEDEEEINAELTAKKRKLEDECSELKKDIDD 959 LELTLAKVEKEKHATENKVKNLTEEMAGLDEI IAKLTKEKKALQEAHO GALDDLQVEEDK 1018 LELTLAKVEKEHATENKVKNFTEEMAVLDETIAKLTKEKKALEAHQQTLDDLVEEDK

VNSLSKSKVKLEQQVDDLEGSLEQEKKVRMDLERAKRKLEGDLKLTOES IMDLENDKLQL 1078 VNTLTKAKTKLEQQVDDLEGSLEQEKKLRMDLERAKRKLEGDLKLAHDSIMDLENDKQQL 1079 EEKLKKKEFDINQQNSKIEDEOVLALQLQKKLKENQARIEELEEELEAERTARAKVEKLR 1138 DEKLKKKDFEISQIQSKIEDEQALGMQLQKKIKELQARIEELEEEIEAERTSRAKAEKHR 1139 SDISRELPEISEDER SDLSRELEEISERLEEAGGATSVQIEMNKKREAEFQKMRRDLEEATLQHEATAAALRKKH 1198 ADLSRELEEISERLEEAGGATAAQIEMNKKREAEFQKMRRDLEEATLQHEATAAALRKKH 119 ADSVAELGEQIDNLQRVKQKLEKEKSEFKLELDDVTSNMEQI IKAKANLEKVSRTLEDQA 1258

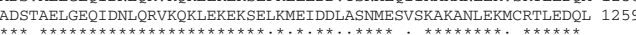
NEYRVKLEEAQRSLNDETTQRAKLQTENGELARQLEEKEALISQLTRGKLSYTQQMEDLK 1318 SEIKTKEEQNQRMINDLNTQRARLQTETGEYSRQAEEKDALISQLSRGKQGFTQQIEELK 1319 RQLEEEGKAKNALAHALQSARHDCDLLREQYEEETEAKAELQRVLSKANSEVAQWRTKYE 1378 RHLEEEIKAKNALAHALQSARHDCELLREQYEEEQEAKGELQRALSKANSEVAQWRTKYE 1379 TDAIQRTEELEEAKKKLAQRLQDAEEAVEAVNAKCSSLEKTKHRLQNEIEDLMVDVERSN 1438 TDAIQRTEELEEAKKKLAQRLQDAEEHVEAVNAKCASLEKTKQRLQNEVEDLMVDVERSN 1439

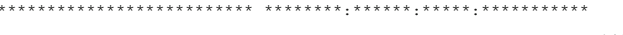
KQRNFDKILAEWKQKYEESQSELESSQKEARSLSSTETKMKNAYEESLDHL 149

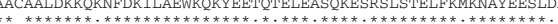

TFKRENKNLQEEISDLTEQLGGEGKNVHELEKVRKQLEVEKLELLSALEEAEASLEHEEG 1558 TLKRENKNLQQEIADLTEQIAEGGKAVHELEKVKKHVEQEKSELQASLEEAEASLEHEEG 155 MYBP-C KILRAQLEFNQIKAETERKLAEKDEEMEQAKRNHQRVDSLQISLDAETRSRNEVLRVKK 161

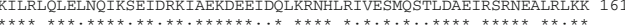
KMEGDLNEMEIQLSHANRMAAEAQKQVKSLLSLLKDTQIQLDDAVRANDDLKENIAIVER 1678 KMEGDLNEMEIQLSHANRMAAEAQKNLRNTQGTLKDTQIHLDDALRTQEDLKEQVAMVER 167 RNNLLQAELEELRAVVEQTERSRKLAEQELIETSERVQLLHSQNTSLINQKKKMESDLTQ 1738 RANLLQAEVEELRGALEQTERSRRVAEQELLDATERVQLLHTQNTSLINTKKKLETDIVQ 173 LQSEVEEAVQECRNAEEKAKKAITDAAMMAEELKKEQDTSAHLERMKKNMEQTIKDLQHR 1798 IQSEMEDT IQEARNAEEKAKKAITDAAMMAEELKKEQDTSAHLERMKKNMDQTVKDLHVR 179 LDEAEQIALKGGKKQLQKLEARVRELEGELEAEQKRNAESVKGMRKSERRIKELTYQTEE 1858 LDEAEQLALKGGKKQLQKLEARVRELEGEVDSEQKRSAEAVKGVRKYERRVKELTYQCEE 1859

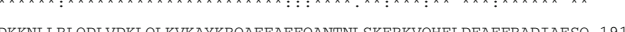
DRKNILRLODLVRLOMKVKSYKROAEEAEELSNVNLSKFRKIQHELEEAEERADIAESQ 1919

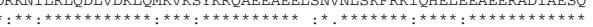
VNKLRAKSRDIGAKOKMHDEE 1939 VNKLRVKSREIHGKKIEE-EE 1939

Fig. 5 Comparison of human and chick $\alpha \mathrm{MHC}$ protein sequences. The human $\alpha$ MHC protein sequence (NP_002462) is compared to the chick sequence (NP_001013415), with various structural domains denoted on the human sequence [158]. The sequences were aligned in ClustalW2 [159, 160]. The nucleotide (ATP)-binding pocket is in part composed of P loop, Loop I, and Switch I with Switch II also important in its function. The rigid relay loop is proposed to connect the ATP binding site to the converter domain. The Strut and Loop 2 are regions that bind the upper and lower 50-kDa subdomains. Switch II is thought to be important in forming a kink, and allowing movement of the converter domain. The converter domain is a socket for the carboxy terminal helical tail and is where rotation occurs around the SH1 helix (also termed the "fulcrum" within the literature), allowing bending of the molecule. The proposed domains for the binding of titin and myosin binding protein-C (MyBP-C) are also denoted (underlined) [161, 162]. ELC essential light chain, $R L C$ regulatory light chain, asterisk fully conserved residues, colon residues with strongly similar properties conserved; period residues with weakly similar properties conserved. Missense mutations previously described in the human MYH6 gene [2, 58, 59] and listed in Table 2 are denoted (boxed)

$m y h 7$ is seen during and upon completion of chamber specification in the zebrafish embryo [53, 63].

Although numerous mutations in $M Y H 7$ are known to be associated with cardiomyopathy [64], in recent years CHDs have also been linked to this gene. A large family with left ventricular non-compaction was found to carry a mutation in the cDNA of the $M Y H 7$ gene at $842 \mathrm{G}>\mathrm{C}$, with four individuals also afflicted with an ASD and/or Epstein's anomaly (EA; malformed tricuspid valve) [65]. This mutation led to a positively charged arginine being replaced by an uncharged threonine (R281T) and was predicted to prevent a salt bridge from forming, leading to instability in the myosin head. A further six missense mutations and one small deletion (of a glutamine residue) have also recently been described, which have been associated with defects including ASD, VSD, and EA [66]. However, the functional significance of these mutations still needs to be elucidated. To our knowledge, transgenic mice with deletion of the $M y h 7$ gene causing defects during cardiogenesis have not been described. When our laboratory knocked down $\beta \mathrm{MHC}$ during early stages of heart development in the chick, all of the morpholino positive embryos had an enlarged heart, but the atrial septa and other structures within the heart were found to be normal (Dr. Catrin Rutland and SL, unpublished data). Further, as seen with $\alpha \mathrm{MHC}$, the atrial and ventricular cardiomyocytes had normal action potentials, although irregular $\mathrm{Ca}^{2+}$ transients were seen in atrial and ventricular cells [42]. Defects in calcium signaling may lead to defects in contraction of the heart, with MHC known to be important for induction of contraction [67-69]. Two fish models have been used to analyze the presumptive functional orthologue to $M Y H 7$. The zebrafish has a shorter developmental period in comparison to the medaka fish, with hatching occurring 
at $48 \mathrm{~h}$ post-fertilization in the zebrafish and 8 days in the medaka fish. The zebrafish half-hearted mutant forms due to a $\mathrm{C}$ to $\mathrm{T}$ transition at position $3,094 \mathrm{bp}$ of the cDNA, which results in a stop codon within the tail region and hence a non-functional truncated protein [70]. These mutant embryos have an enlarged and distended ventricular chamber, which fails to contract, with a normally formed atrium. In the medaka fish, the hozuki mutants form due to a nonsense mutation (an A to T transition) in the myh7 gene that leads to a loss of most of the tail domain [71]. These mutants have an enlarged ventricle, which can be seen from cardiac looping (stage 30), with excessive cardiomyocyte formation and fewer myofibrils in the ventricle. The atrium appears normal and the hozuki mutant embryos survived until hatching.

\section{Myosin heavy chain $7 b$}

In the adult human heart, $M Y H 7 B$ transcripts were detected by RT-PCR [72] with the developing heart not investigated. In mice, in situ hybridization showed that $M y h 7 b$ is expressed in the developing heart throughout the myocardium of the atrial and ventricular regions [72]. Expression is also detected in the adult heart, in somites and skeletal muscle and tissues such as the brain and the smooth muscle layer of large blood vessels [72-74]. In the chick, expression of $M Y H 7 B$ is found in the developing heart from early stages and in the day 19 post-hatched heart, throughout the myocardium [72], as seen in the mouse. Intriguingly, this expression in the chick contrasts with a previous study that detected $M Y H 7 B$ in the Purkinje fibers of the heart just prior to hatching, and absent to the myocardium [72, 75]. This discrepancy is currently not understood. In Xenopus, expression of $m y h 7 b$ is found in the developing heart and in the adult [72]. Expression was also observed in somites in both chick and Xenopus. However, despite the expression of $M Y H 7 B$ is now known in a number of species, its function is currently poorly understood.

\section{Myosin heavy chain 9}

The nonmuscle myosin, NMHC IIA, is expressed in the human heart. However, it is expressed in the smooth muscle, endothelial, and fibroblast cells of the heart, not in cardiomyocytes [76]. Expression was seen at two stages; 19 weeks of development and in the adult. The expression of NMHC IIA in the murine heart is similar to human; smooth muscle, endothelial and fibroblast cells express $M y h 9$, but cardiomyocytes do not [76]. During development, Myh9 transcripts are found in the E9.5 mouse and the HH12 chick heart, stages when the heart is undergoing looping in both species [77]. NMHC IIA is also expressed in a number of other tissues such as lung, liver, and kidney.
To date, mutations in this gene have not been associated with abnormalities in the heart.

Myosin heavy chain 10

The nonmuscle myosin protein NMHC IIB is widely expressed. In the heart, it is expressed to smooth muscle cells, endothelial cells, fibroblasts, and cardiomyocytes [76]. Immunostaining found NMHC IIB to be diffuse throughout the cytoplasm in human fetal cardiomyocytes at 19 weeks of gestation. In the adult human heart, NMHC IIB is restricted to the Z-lines and intercalated discs [76]. A similar expression pattern is seen for the mouse. Myh10 expression is seen in the early looping heart in both mouse (at E9.5) and chick (at HH12) [77].

To our knowledge, mutations in the MYH1O gene have not been found in humans. However, Myh10 ablation in the mouse leads to embryonic lethality by E14.5 in most embryos, with a variety of defects in the heart, including VSDs, double-outlet right ventricle (DORV; the origin of the aorta is abnormally located from the right ventricle) and hypertrophic cardiomyocytes seen at high penetrance [78]. Many null Myh10 embryos upregulated NMHC IIA, a potential compensatory mechanism for non-heart tissues that express Myh10. Of the null mutants that were live born, death occurred on postnatal day 1 due to congestive heart failure [78]. The heterozygous mice were normal. Cardiomyocyte-specific knockout of Myh10, using the loxP/Cre recombinase system, lead to mutant mice born with hypertrophic myocytes [79]. These mice also had VSDs (seen at low penetrance as expression levels were reduced only from mid-gestation) although DORV was not observed. Subsequently, cardiomyopathy was seen, with the presentation of the phenotype observed between 6 and 10 months postnatally [79]. In addition, the intercalated discs appeared wider than in controls and some of the cardiomyocytes were multinucleated. The related nonmuscle proteins NMHC IIA and NMHC IIC were not found to be upregulated in these mutant mice. A role for NMHC IIB has been suggested in the spreading of cardiomyocytes, and hence in the regulation of cell size [80]. Other animal models have not been investigated to date.

\section{Myosin heavy chain 11}

The protein product of the MYH11 gene is SM-MHC, which is a contractile protein of smooth muscle cells. It is expressed in cells derived from smooth muscle lineages; expression is seen from the E10.5 aorta in the mouse, and later in development in peripheral blood vessels, intestine, bladder, and uterus [81]. Interestingly, expression is absent 
to organs such as the heart, kidney, and brain except to the vasculature.

Mutational analysis of MYHII was performed in two kindreds afflicted with thoracic aortic aneurysm and/or aortic dissection (TAAD) with three mutations detected [82]. It was proposed that the location of the mutations may affect the coiled-coil structure of the C-terminal region of this smooth muscle MHC protein, and hence the assembly of myosin thick filaments. A dominant-negative effect of the mutations was proposed [82]. Further, symptomatic individuals with the mutation were found to have a lower aortic compliance and a higher pulse wave velocity, leading to a severe decrease in the elasticity of the aortic wall. Subsequently, three MYH11 missense mutations have been linked to individuals with TAAD and patent ductus arteriosus (PDA; the ductus arteriosus fails to close postnatally) [83, 84] and rarely to isolated PDA [84]. Amino acid residue changes $\mathrm{L} 1264 \mathrm{P}$ and $\mathrm{R} 1275 \mathrm{~L}$, due to mutations 3,791 $\mathrm{T}>\mathrm{C}$ and 3,824 $\mathrm{G}>\mathrm{T}$, respectively, were located in the coiled-coiled region whereas residue alteration $\mathrm{R} 712 \mathrm{Q}$, caused by the $2,153 \mathrm{C}>\mathrm{T}$ mutation, was located in the ATPase head domain [83]. The R712Q mutation was predicted to destabilize the SH1 helix and hence prevent the motor domain and lever arm from communicating effectively. Mutations to the coiled-coiled domain were predicted to affect protein-protein interactions. Histological analysis was performed on tissue from affected individuals; smooth muscle cells were found to be disorganized and show hyperplasia in the aortic media, leading to lumen narrowing in some vessels [83]. Further missense mutations associated with isolated PDA were R669C (mutation 2,005 C to T in the cDNA) and E1290Q (3,868 $\mathrm{G}$ to $\mathrm{C}$ in the cDNA) [84]. The R669C mutation was in the globular head of SM-MHC, a region predicted to play a role in actin binding, whereas E1290Q was located in the tail. Other variants were also described in this study, but were also seen in controls. Consistent with the PDA phenotype seen in some affected individuals, Myh11 knockout mice were also found to have delayed closure of the ductus arteriosus [85].

\section{Myosin heavy chain 14}

As with the other nonmuscle myosins, the protein product of $\mathrm{MYH14}$ is widely expressed. With regards to the heart, NMHC IIC is expressed in cardiomyocytes of the mouse E13.5 heart, with immunofluorescence restricted in the intercalated discs of the adult heart [86]. Mutations in the human $\mathrm{MYH14}$ gene have not been associated with defects in heart formation or function. Although expressed in the heart, the Myh14 mouse knockout appeared normal and survived to adulthood [86].

\section{The myosin light chains}

As with the myosin heavy chains, the nomenclature for the myosin light chains has also varied within the literature. In this review, the genes have been named according to the nomenclature described by the HUGO gene nomenclature committee, but as with the heavy chains, the proteins have been named in line with the general literature. In addition, in this review, myosin light chain is abbreviated to MYL for the gene and MLC for the protein product.

As mentioned above, two types of MLCs exist; the essential (MLC1; also known in the literature as ELC or alkali MLC) and regulatory light chains (MLC2; also known as RLC or phosphorylatable MLC). Both types are associated with the neck region of the MHC. To date, eight genes encode mammalian MLC, with each isoform having a distinct expression profile. There are four MLC1 genes: MYL1 (chromosome 2q24.11), MYL3 (chromosome 3p21.3), MYL4 (chromosome 17q21.32) and MYL6 (chromosome 12q13.2). MYL1, MYL3, and MYL4 are expressed in striated muscle, while MYL6 is a nonmuscle and smooth muscle myosin. There are also four MLC2s: the sarcomeric MYL2 (chromosome 12q24.11), MYL5 (chromosome 4p16.3) and MYL7 (chromosome 12q13.2), and the smooth muscle MYL9 (chromosome 20q11.23). For a summary of gene names, human chromosomal location and protein name, see Table 1.

MYL3, MYL4, MYL2, and MYL7 are expressed in the heart in a restricted manner during development and have been shown to play a key role in cardiogenesis. Again, the nomenclature for the MLCs has varied in the literature. MYL3 is also known as MLC1v, ELCv or VLC1, while MYL4 is commonly referred to as the MLC1a, embryonic MYL, ELCa or ALC1. MYL2 of the MLC2s are also named MLC2v or RLCv, and MYL7 is known as MLC2a or RLCa.

\section{The myosin light chains and the cardiovascular system}

The expression and function for each myosin light-chain gene, which plays a potential role in heart development, is discussed. The effects of altering MYL gene expression on the developing heart are summarized in Table 2.

Myosin light chain 2

MLC2v is restricted to the ventricles, both throughout the developing and adult human heart [87]. Expression of $M y l 2$ is also restricted to the ventricular cardiomyocytes of the heart tube in rodents (mouse and rat) $[88,89]$. As the heart tube begins to fold, expression is also detected in the 
proximal outflow tract; however this expression only remains until ventricular septation commences [89]. Chick expression of MYL2 appears similar to that of the mouse and always remained restricted to the ventricular portion of the heart, but is also detected as early as $\mathrm{HH} 5$, prior to heart tube formation [90, 91].

Mutations of the human MYL2 gene have been associated with hypertrophic cardiomyopathy [92-97]. Lack of Mlc2v in mice is embryonic lethal (E12.5) due to cardiac dysfunction that results in heart failure. Hearts dissected from these embryos showed massive cardiac enlargement, wall thinning, dilation of the chambers, and pleural effusions. Upon ultrastructural analysis of these hearts, abnormalities in myofibril assembly were seen, displaying disorganized alignment of the thick and thin filaments, narrow fibers, and larger distances between Z-bands in the homozygous null in comparison to wild-types [97]. Knockdown of MYL2 in the chick resulted in cardiac anomalies, including irregular heart looping and, again, poorly developed sarcomeres such that Z-discs appeared as dense irregular shapes instead of properly formed bands [91].

\section{Myosin light chain 3}

MLC1v expression is restricted to the ventricular segment of the linear heart tube throughout development and in the adult human heart [98]. This expression is also seen in the mouse [99]. In the Xenopus, Myl3 expression is detected in the somatic mesoderm during the tail bud stage and from stage 31 , just prior to heart tube formation, and is detected in the precursor cells of the myocardium, but becomes restricted to the ventricular region of the heart after looping [100].

MLC1v is expressed in the atria of children with perimembranous VSDs and tetralogy of Fallot (a CHD that involves four defects-overriding aorta, pulmonary stenosis, VSD, and right ventricular hypertrophy) [101]. Mutations of MYL3 have been associated with familial hypertrophic cardiomyopathy (FHC), and, although these mutations are rare when compared with mutations in MYH7, the outcomes of these mutations are quite malignant. Ten mutations of the MYL3 gene have been associated with FHC, all of which have been found on the EF-hand domain of the protein [94, 96, 102-107].

\section{Myosin light chain 4}

Human embryonic whole hearts express MLC1a, as well as in skeletal muscle [108]. However, postnatally, protein levels decrease to undetectable levels in the ventricles but remain in the atria [109]. Mlc1a in Xenopus is extensively expressed in myocardial cells at stage 31 [100]. Zebrafish express only one MLC1, cmlc1, in a cardiac-specific manner and this MLC1 is the orthologue to human MLC1a [110].

A change in expression of MLC1a to other regions apart from the atrium postnatally has been associated with CHDs and cardiomyopathies, linked with pressure overload. Children with tetralogy of Fallot were shown to express large amounts of MLC1a in the ventricles, replacing the endogenous MLC1v of this region [111]. This was also the case in the hypertrophied left ventricle of patients with ischemic, dilative, and hypertrophic cardiomyopathy [112-114]. These isoform switches appear to be compensatory mechanisms of the heart, causing increased cycling kinetics of the cross-bridge cycle, and hence, regulating contraction of the affected heart [22]. This isoform switch was also studied in the mouse. Transgenic overexpression of Myl4 leads to high levels of expression in the ventricles, replacing the endogenous Myl3 [115]. Although the isoform shift was benign, with no pathology observed, there was improved cardiac function in the mouse hearts. Knockdown of $\mathrm{cmlcl}$ in zebrafish resulted in failure of the assembly of Z-bands from the Z-bodies [110]. In addition, the thick filaments appear less dense as they fail to align and assemble properly into A-bands within the sarcomere during development, increasing sarcomeric length. End systolic ventricular volume of $\mathrm{cmlcl}$ knockdowns was greater than that of wild-types indicating the morphant hearts can dilate but not contract sufficiently [110]. These results suggest a vital role for MLC1 in sarcomeric assembly and fine-tuning of cardiac contractility.

\section{Myosin light chain 7}

MLC2a is expressed in humans at high levels in the atrium postnatally, throughout the linear heart during development, and can also be detected in the adult ventricles, but at lower levels [116]. In the mouse, Myl7 is initially expressed throughout the linear heart tube early in development (E7.5); however, it becomes restricted to the atria after E12.5 [117]. Expression is similar in the rat [88]. Although expression is seen throughout the linear heart tube, the protein is incorporated in the myofibrils of the atria only, not into the ventricular myofibrils [97]. The $m l c 2$ gene is the Xenopus orthologue of human MYL2 [118]. It is expressed early in development in the cardiac mesoderm and in subsequent steps of heart tube formation, looping, and chamber septation where it is not restricted to any one area of the myocardium [119]. Zebrafish show strong expression of only one isoform of MLC2s in the heart, cmcl2, which is thought to be the zebrafish orthologue of human MLC2a [110, 120]. Cmcl2 is expressed in the 13 somite stage (prior to heart tube formation) zebrafish 
embryo, and is expressed throughout the myocardium of the heart by the time heart looping has occurred [63].

Mutations in MYL7 have not yet been associated with human disease to our knowledge. Myl7 null mice were found to be embryonic lethal between E10.5-11.5, and unusual cardiac morphogenesis was apparent in the early linear heart tube (E7.5) such as enlargement of the heart tube and abnormal morphogenesis in the looping heart tube. They also presented with enlarged atria and outflow tracts. The ventricles displayed thin walls, with underdeveloped trabeculae and left ventricular dilation was apparent. At the ultrastructural level, the myofibrils in the atria were disorganized, with a lack of alignment of the thick and thin filaments, associated with diminished beating in the atrial chamber, while cardiomyocytes in the ventricles appeared normal [121]. Chimeric mice of chromosome 21, used as an animal model for Down's syndrome, showed post-transcriptional down-regulation of endogenous $M y l 7$, which was also seen in human patients [122]. As more than $50 \%$ of Down's syndrome patients have a CHD, this study suggests a potential role for MLC2a in CHDs. Knockdown of $\mathrm{cmcl} 2$ using morpholino oligonucleotides in the zebrafish results in a number of defects in cardiogenesis. Assembly of the dotted Z-bodies into Z-discs failed and previously assembled thick filaments did not align into A-bands, with the sarcomeres of decreased length. Cardiac contractility was reduced, as was the ventricular chamber volume [110]. These data indicate that MLC2s are important in myofibrillogenesis and cardiac contractility. Mutations in the $c m c l 2$ gene were also studied. The tell-tale mutation $t^{m} l^{m 225}$ is a fully penetrant embryonic lethal recessive mutation that perturbs cardiac contractility in early embryonic development [120]. Although heart tube formation appears normal, with the two heart chambers of normal size, strong peristaltic contractions of the chamber seen in the wild-type are weaker in the $t e l^{m 225}$ mutant. This is the result of disturbances of thick filament assembly of the sarcomere, suggesting a role for MLC2 in sarcomerogenesis [120].

\section{The role of transcription factors in the regulation of myosin}

Structural proteins are the downstream targets of transcription factors that control heart formation in a tightly controlled manner. Therefore, considering the critical role these transcription factors play in cardiogenesis, it is not surprising that a number of these genes have also been found to form CHDs when mutated. The first cardiac transcription factor associated with a CHD was in 1998 in the homeobox gene $N K X 2.5$, with mutations found in probands predominately afflicted with an ASD and conduction defects [123]. Subsequently, mutations have been found in numerous other cardiac transcription factors, such as GATA4 [124], and the T-box genes TBX5 [125, 126] and $T B X 20$ [127]. It is also of interest that many of these transcription factors have synergistic effects, and are upstream of other cardiac transcription factors or genes such at the natriuretic factors NPPA (natriuretic peptide precursor a, also known as atrial natriuretic factor) and $N P P B$ (natriuretic peptide precursor $\mathrm{b}$, also known as brain natriuretic factor) [128-132]. Serum response factor $(S R F)$ is a ubiquitous transcription factor that elicits its effect on cardiac and smooth muscle genes by associating with its cofactor myocardin. Myocardin is also known to interact with a number of other cofactors [133].

As stated above, $\beta$ MHC is specifically expressed to the ventricle [48, 49]. In zebrafish, the lack of $m y h 7$ expression in the atrium is regulated by $\mathrm{Nkx} 2.5$ [134]. The zebrafish homeobox transcription factor Prx 2 and the mouse Gata factors Gata4 and Gata6 have also been shown to regulate $m y h 7$ expression $[131,134,135]$. However, in embryonic hearts isolated from compound heterozygote Gata4/Tbx5 mice, mRNA expression of $M y h 7$ was found to be unaffected, unlike Myh6, which showed decreased expression in the compound heterozygote but not in the single Gata4 and Tbx5 heterozygotes [130]. Myh6 is also regulated by important cardiac transcription factors. Both GATA4 and TBX5 activate Myh6 expression in rodents in vitro $[2,132,136]$. In addition, the transcription factor myocardin, which is a cofactor for SRF and TBX5, activated Myh6 [137, 138]. In contrast, Gata4/Gata6 compound heterozygote mice did not show decreased Myh6 expression, despite these mice having a range of heart defects [131]. Bmp-4 is also thought to be important in the mediation of sarcomeric myosin expression in Xenopus [139]. IRX4 (iroquois homeobox 4) is a transcription factor that is ventricular specific; it has a role in myosin regulation by activating $M Y H 7$ to be expressed in the ventricle while suppressing MYH6 [140]. Activation of the $M y h 7 b$ mouse promoter was shown to occur via Gata, Mef2, and E-box binding sites, with the Mef2 site being the most important [72]. Interestingly, other conserved regulatory elements were found to be important in $M y h 7 b$ expression, although the proteins that bind to these sites have yet to be identified.

In comparison to the sarcomeric myosins, the regulation of the nonsarcomeric myosins in the heart is poorly understood. GATA6 has been shown to be important in the activation of the smooth muscle Myhl1 gene, with GATA6 forming a complex with the transcriptional coactivator p300 [141]. In contrast to Myh6, Myhll was not activated by the myocardin/TBX5 complex [142]. However, myocardin has been shown to activate smooth muscle Myhll via other cofactors including SRF [142-144]. 
MYLs are also regulated by a number of transcription factors. Unlike mammals, Xenopus has only one regulatory MYL. Enhancer elements within the promoter region of this gene have been shown to be essential for the heartspecific expression in Xenopus [119]. Additional in vitro studies in Xenopus of the Gata motifs and an SRF site within this MYL promoter region were shown to be necessary for this specific expression, and over-expression of gata6 has been associated with a lack of mlc2 expression $[119,145]$. Further, gata and $s r f$ genes were shown to act synergistically in regulation of the regulatory $m y l$ in the frog [119]. This is supported by another study in Xenopus that demonstrated that regulatory $m y l$ is activated via the srf cofactor myocardin interacting with gata4; this contrasted with myh6 which could be activated by each factor independently [138]. As stated previously in this review, MLC phosphorylation is regulated by myosin light chain kinase (MLCK). Interestingly, Mlck is also regulated by the cardiac transcription factor Nkx2.5 [146].

\section{Micro RNAs in the regulation of myosin}

Additional regulation of cardiac transcription factors and myosin genes is via noncoding RNAs, notably miRNAs. miRNAs are known to be important in a number of biological processes, such as cell proliferation, differentiation, and apoptosis [147]. miRNAs modulate gene expression predominately by acting as negative regulators by inducing the degradation or inhibiting the translation of target mRNAs. Mature miRNAs are approximately 22 nucleotides long, with their formation involving two RNase III enzymes Drosha and Dicer [148, 149]. The extent to which miRNAs play in heart development is currently not fully understood, though is likely to be complex, as any one miRNA may regulate more than one target, and more than one miRNA can bind to the same gene. The role that miRNAs play in cardiac transcription factor regulation is beyond the scope of this review, with a number of excellent reviews recently published [147, 150]. However, it is relevant to summarize the recent data demonstrating a role for miRNAs in the regulation of the myosin genes.

Intergenic, intronic, and exonic miRNAs can occur, with the exonic miRNAs being expressed with the host gene. Intergenic and intronic miRNAs have their own regulatory elements. Embryonic stem cells undergo mesodermal differentiation to a myocardial lineage, with miR-1 and miR133 playing critical roles in controlling this process [151, 152]. Further, miR-1 has been shown to be important for cardiomyocyte differentiation and its overexpression was found to repress $M y h 6[152,153]$. With regards to the myosin genes having their own miRNAs, three intronic miRNAs have been located within cardiac myosin heavy-chain genes.
miR-208a is located in intron 27 of the human and mouse MYH6 gene [154], with the related miR-208b located in intron 31 of $M Y H 7$ [73] and miR-499 is within intron 19 of the $M Y H 7 B$ gene [155]. In the mouse, the expression of these miRNAs correlates with their host genes, with miR-208a mainly expressed in the adult heart, miR-208b predominately expressed in the developing heart and miR-499 expressed during cardiac morphogenesis and in the adult [74, 156]. Although miR-208a, miR-208b, nor miR-499 seem to function during mouse cardiogenesis, miR-208a was shown to be the dominant miRNA in the adult heart, by upregulating $M y h 7$ transcripts in response to stress [73, 154]. However, as other larger animals express MYH6 and MYH7 differently to mice, the expression and function of miR-208a and miR$208 \mathrm{~b}$ could also be different. Consistent with this, an in vitro study using human cardiomyocytes progenitors suggests a role for miR-499 in differentiation [153], with overexpression of miR-499 in human embryoid bodies leading to significant upregulation of $M Y H 7$ [155].

\section{Conclusions and future perspectives}

Myosin structural proteins are expressed in a restricted manner in the developing heart and play vital roles in early cardiogenesis. In this review, we have shown that changes in expression can lead to detrimental effects on the developing heart, with a variety of phenotypes seen. However, there remain many gaps in knowledge with as yet a comprehensive understanding of the role myosin heavy and light chains play in cardiogenesis still lacking. In the future, further genetic and molecular studies will elucidate precise roles for the myosins in heart development and how the myosins are regulated at different developmental stages. Such insights should improve genetic counseling and may lead to therapeutic treatments of CHDs, cardiomyopathies, and other cardiac anomalies. Already myosin-activating drugs have gone on trial for the treatment of heart failure. These activators work by increasing the transition rate of the weakly bound actomyosin complex to a strongly bound one, therefore increasing cardiac contraction [157]. A greater understanding of the role and regulation of myosin structural proteins should help pave the way for creating a detailed molecular map of heart development.

Acknowledgments We would like to thank Dr. Catrin Rutland for reading this article and Dr. Javier Granados-Riveron for helpful discussions.

Open Access This article is distributed under the terms of the Creative Commons Attribution License which permits any use, distribution, and reproduction in any medium, provided the original author(s) and the source are credited. 


\section{References}

1. van der Linde D, Konings EE, Slager MA, Witsenburg M, Helbing WA, Takkenberg JJ, Roos-Hesselink JW (2011) Birth prevalence of congenital heart disease worldwide: a systematic review and meta-analysis. J Am Coll Cardiol 58:2241-2247

2. Ching YH, Ghosh TK, Cross SJ, Packham EA, Honeyman L, Loughna S, Robinson TE, Dearlove AM, Ribas G, Bonser AJ, Thomas NR, Scotter AJ, Caves LS, Tyrrell GP, Newbury-Ecob RA, Munnich A, Bonnet D, Brook JD (2005) Mutation in myosin heavy chain 6 causes atrial septal defect. Nat Genet 37:423-428

3. Fürst DO, Osborn M, Nave R, Weber K (1988) The organization of titin filaments in the half-sarcomere revealed by monoclonal antibodies in immunoelectron microscopy: a map of ten nonrepetitive epitopes starting at the $\mathrm{z}$ line extends close to the $\mathrm{m}$ line. J Cell Biol 106:1563-1572

4. Ferrans VJ, Rodriguez ER (1991) Ultrastructure of the normal heart. Churchill Livingstone, New York

5. Danowski BA, Imanaka-Yoshida K, Sanger JM, Sanger JW (1992) Costameres are sites of force transmission to the substratum in adult rat cardiomyocytes. J Cell Biol 118:14111420

6. Tokuyasu KT, Maher PA (1987) Immunocytochemical studies of cardiac myofibrillogenesis in early chick embryos. I. Presence of immunofluorescent titin spots in premyofibril stages. J Cell Biol 105:2781-2793

7. Imanaka-Yoshida K, Knudsen KA, Linask KK (1998) N-cadherin is required for the differentiation and initial myofibrillogenesis of chick cardiomyocytes. Cell Motil Cytoskelet 39:52-62

8. Du A, Sanger JM, Sanger JW (2008) Cardiac myofibrillogenesis inside intact embryonic hearts. Dev Biol 318:236-246

9. Rhee D, Sanger JM, Sanger JW (1994) The premyofibril: evidence for its role in myofibrillogenesis. Cell Motil Cytoskelet 28:1-24

10. Suzuki H, Komiyama M, Konno A, Shimada Y (1998) Exchangeability of actin in cardiac myocytes and fibroblasts as determined by fluorescence photobleaching recovery. Tissue Cell 30:274-280

11. Turnacioglu KK, Mittal B, Dabiri GA, Sanger JM, Sanger JW (1997) An N-terminal fragment of titin coupled to green fluorescent protein localizes to the z-bands in living muscle cells: overexpression leads to myofibril disassembly. Mol Biol Cell 8:705-717

12. Van Der Ven PFM, Ehler E, Perriard J-C, Fürst DO (1999) Thick filament assembly occurs after the formation of a cytoskeletal scaffold. J Muscle Res Cell Motil 20:569-579

13. Huxley H (1963) Electron microscope studies on the structure of natural and synthetic protein filaments from striated muscle. J Mol Biol 7:281-308

14. Harrington WF, Rodgers ME (1984) Myosin. Annu Rev Biochem 53:35-73

15. Cheney RE, Riley MA, Mooseker MS (1993) Phylogenetic analysis of the myosin superfamily. Cell Motil Cytoskelet 24:215-223

16. Warrick HM, Spudich JA (1987) Myosin structure and function in cell motility. Annu Rev Cell Biol 3:379-421

17. Harrington WF (1979) On the origin of the contractile force in skeletal muscle. Proc Nat Acad Sci 76:5066-5070

18. Rayment I, Rypniewski W, Schmidt-Base K, Smith R, Tomchick D, Benning M, Winkelmann D, Wesenberg G, Holden H (1993) Three-dimensional structure of myosin subfragment-1: a molecular motor. Science 261:50-58

19. Mornet D, Pantel P, Audemard E, Kassab R (1979) The limited tryptic cleavage of chymotryptic s-1: an approach to the characterization of the actin site in myosin heads. Biochem Biophys Res Commun 89:925-932

20. Geeves MA (2002) Molecular motors: stretching the lever-arm theory. Nature 415:129-131

21. Moncrief ND, Kretsinger RH, Goodman M (1990) Evolution of EF-hand calcium-modulated proteins. I. Relationships based on amino acid sequences. J Mol Evol 30:522-562

22. Morano M, Zacharzowski U, Maier M, Lange PE, Alexi-Meskishvili V, Haase H, Morano I (1996) Regulation of human heart contractility by essential myosin light chain isoforms. J Clin Invest 98:467-473

23. Ogut O, Brozovich FV (2003) Regulation of force in vascular smooth muscle. J Mol Cell Cardiol 35:347-355

24. Timson DJ, Trayer HR, Trayer IP (1998) The N-terminus of A1-type myosin essential light chains binds actin and modulates myosin motor function. Eur J Biochem 255:654-662

25. VanBuren P, Walker G, Harris D, Trybus K, Warshaw D, Lowey S (1995) The essential light chain is required for full force production in skeletal muscle myosin. Biophys J 68:345s

26. Eisenberg E, Hill TL (1985) Muscle contraction and free energy transduction in biological systems. Science 227:999-1006

27. Brenner B, Yu LC (1993) Structural changes in the actomyosin cross-bridges associated with force generation. Proc Natl Acad Sci USA 90:5252-5256

28. Bagshaw CR, Trentham DR (1973) The reversibility of adenosine triphosphate cleavage by myosin. Biochem J 133:323-328

29. Uyeda TQP, Kron SJ, Spudich JA (1990) Myosin step size: estimation from slow sliding movement of actin over low densities of heavy meromyosin. J Mol Biol 214:699-710

30. Maughan D (2005) Kinetics and energetics of the crossbridge cycle. Heart Fail Rev 10:175-185

31. Lehman W, Craig R, Vibert P (1994) Ca2+-induced tropomyosin movement in limulus thin filaments revealed by threedimensional reconstruction. Nature 368:65-67

32. Pan BS, Solaro RJ (1987) Calcium-binding properties of troponin $\mathrm{c}$ in detergent-skinned heart muscle fibers. J Biol Chem 262:7839-7849

33. Vibert P, Craig R, Lehman W (1997) Steric-model for activation of muscle thin filaments. J Mol Biol 266:8-14

34. Lehrer SS (1994) The regulatory switch of the muscle thin filament: $\mathrm{Ca}^{2+}$ or myosin heads? J Muscle Res Cell Motil $15: 232-236$

35. Stull J, Nunnally M, Moore R, Blumenthal D (1985) Myosin light chain kinases and myosin phosphorylation in skeletal muscle. Adv Enzyme Regul 23:123-140

36. Davis JS, Satorius CL, Epstein ND (2002) Kinetic effects of myosin regulatory light chain phosphorylation on skeletal muscle contraction. Biophys J 83:359-370

37. Trybus K (1994) Role of myosin light chains. J Muscle Res Cell Motil 15:587-594

38. Horowitz A, Menice CB, Laporte R, Morgan KG (1996) Mechanisms of smooth muscle contraction. Physiol Rev 76:967-1003

39. Moss RL, Fitzsimons DP (2006) Myosin light chain 2 into the mainstream of cardiac development and contractility. Circ Res 99:225-227

40. Ishikawa Y, Kurotani R (2008) Cardiac myosin light chain kinase. Circ Res 102:516-518

41. Sweeney HL, Bowman BF, Stull JT (1993) Myosin light chain phosphorylation in vertebrate striated muscle: regulation and function. Am J Physiol Cell Physiol 264:C1085-C1095

42. Rutland CS, Polo-Parada L, Ehler E, Alibhai A, Thorpe A, Suren S, Emes RD, Patel B, Loughna S (2011) Knockdown of embryonic myosin heavy chain reveals an essential role in the morphology and function of the developing heart. Development 138:3955-3966 
43. Gulick J, Kropp K, Robbins J (1987) The developmentally regulated expression of two linked myosin heavy-chain genes. Eur J Biochem 169:79-84

44. Lagrutta AA, McCarthy JG, Scherczinger CA, Heywood SM (1989) Identification and developmental expression of a novel embryonic myosin heavy-chain gene in chicken. DNA 8:39-50

45. Sacks LD, Cann GM, Nikovits W Jr, Conlon S, Espinoza NR, Stockdale FE (2003) Regulation of myosin expression during myotome formation. Development 130:3391-3402

46. Toydemir RM, Rutherford A, Whitby FG, Jorde LB, Carey JC, Bamshad MJ (2006) Mutations in embryonic myosin heavy chain (myh3) cause Freeman-Sheldon syndrome and SheldonHall syndrome. Nat Genet 38:561-565

47. Alvarado DM, Buchan JG, Gurnett CA, Dobbs MB (2011) Exome sequencing identifies an $\mathrm{MYH} 3$ mutation in a family with distal arthrogryposis type 1. J Bone Joint Surg Am 93(11):1045-1050

48. Reiser PJ, Portman MA, Ning XH, Schomisch Moravec C (2001) Human cardiac myosin heavy chain isoforms in fetal and failing adult atria and ventricles. Am J Physiol Heart Circ Physiol 280:H1814-H1820

49. Wessels A, Vermeulen JL, Viragh S, Kalman F, Lamers WH, Moorman AF (1991) Spatial distribution of "tissue-specific" antigens in the developing human heart and skeletal muscle. II. An immunohistochemical analysis of myosin heavy chain isoform expression patterns in the embryonic heart. Anat Rec 229:355-368

50. Franco D, Lamers WH, Moorman AF (1998) Patterns of expression in the developing myocardium: towards a morphologically integrated transcriptional model. Cardiovasc Res $38: 25-53$

51. Somi S, Klein AT, Houweling AC, Ruijter JM, Buffing AA, Moorman AF, Van Den Hoff MJ (2006) Atrial and ventricular myosin heavy-chain expression in the developing chicken heart: strengths and limitations of non-radioactive in situ hybridization. J Histochem Cytochem 54:649-664

52. Lyons GE, Schiaffino S, Sassoon D, Barton P, Buckingham M (1990) Developmental regulation of myosin gene expression in mouse cardiac muscle. J Cell Biol 111:2427-2436

53. Berdougo E, Coleman H, Lee DH, Stainier DY, Yelon D (2003) Mutation of weak atrium/atrial myosin heavy chain disrupts atrial function and influences ventricular morphogenesis in zebrafish. Development 130:6121-6129

54. Garriock RJ, Meadows SM, Krieg PA (2005) Developmental expression and comparative genomic analysis of Xenopus cardiac myosin heavy chain genes. Dev Dyn 233:1287-1293

55. Carniel E, Taylor MR, Sinagra G, Di LA, Ku L, Fain PR, Boucek MM, Cavanaugh J, Miocic S, Slavov D, Graw SL, Feiger J, Zhu XZ, Dao D, Ferguson DA, Bristow MR, Mestroni L (2005) Alpha-myosin heavy chain: a sarcomeric gene associated with dilated and hypertrophic phenotypes of cardiomyopathy. Circulation 112:54-59

56. Niimura H, Patton KK, McKenna WJ, Soults J, Maron BJ, Seidman JG, Seidman CE (2002) Sarcomere protein gene mutations in hypertrophic cardiomyopathy of the elderly. Circulation 105:446-451

57. Hershberger RE, Norton N, Morales A, Li D, Siegfried JD, Gonzalez-Quintana J (2010) Coding sequence rare variants identified in mybpc3, myh6, tpm1, tnnc1, and tnni3 from 312 patients with familial or idiopathic dilated cardiomyopathy. Circ Cardiovasc Genet 3:155-161

58. Granados-Riveron JT, Ghosh TK, Pope M, Bu'Lock F, Thornborough C, Eason J, Kirk EP, Fatkin D, Feneley MP, Harvey RP, Armour JA, David Brook J (2010) Alpha-cardiac myosin heavy chain (myh6) mutations affecting myofibril formation are associated with congenital heart defects. Hum Mol Genet 19:4007-4016

59. Posch MG, Waldmuller S, Muller M, Scheffold T, Fournier D, Andrade-Navarro MA, De Geeter B, Guillaumont S, Dauphin C, Yousseff D, Schmitt KR, Perrot A, Berger F, Hetzer R, Bouvagnet $\mathrm{P}$, Ozcelik C (2011) Cardiac alpha-myosin (myh6) is the predominant sarcomeric disease gene for familial atrial septal defects. PLoS ONE 6:e28872

60. Jones WK, Grupp IL, Doetschman T, Grupp G, Osinska H, Hewett TE, Boivin G, Gulick J, Ng WA, Robbins J (1996) Ablation of the murine alpha myosin heavy chain gene leads to dosage effects and functional deficits in the heart. J Clin Invest 98:1906-1917

61. Rutland C, Warner L, Thorpe A, Alibhai A, Robinson T, Shaw B, Layfield R, Brook JD, Loughna S (2009) Knockdown of alpha myosin heavy chain disrupts the cytoskeleton and leads to multiple defects during chick cardiogenesis. J Anat 214:905-915

62. Abu-Daya A, Sater AK, Wells DE, Mohun TJ, Zimmerman LB (2009) Absence of heartbeat in the Xenopus tropicalis mutation muzak is caused by a nonsense mutation in cardiac myosin myh6. Dev Biol 336:20-29

63. Yelon D, Horne SA, Stainier DY (1999) Restricted expression of cardiac myosin genes reveals regulated aspects of heart tube assembly in zebrafish. Dev Biol 214:23-37

64. Walsh R, Rutland C, Thomas R, Loughna S (2010) Cardiomyopathy: a systematic review of disease-causing mutations in myosin heavy chain 7 and their phenotypic manifestations. Cardiology 115:49-60

65. Budde BS, Binner P, Waldmuller S, Hohne W, Blankenfeldt W, Hassfeld S, Bromsen J, Dermintzoglou A, Wieczorek M, May E, Kirst E, Selignow C, Rackebrandt K, Muller M, Goody RS, Vosberg HP, Nurnberg P, Scheffold T (2007) Noncompaction of the ventricular myocardium is associated with a de novo mutation in the beta-myosin heavy chain gene. PLoS ONE 2:e1362

66. Postma AV, van Engelen K, van de Meerakker J, Rahman T, Probst S, Baars MJ, Bauer U, Pickardt T, Sperling SR, Berger F, Moorman AF, Mulder BJ, Thierfelder L, Keavney B, Goodship J, Klaassen S (2011) Mutations in the sarcomere gene MYH7 in Ebstein anomaly. Circ Cardiovasc Genet 4:43-50

67. Chandra M, Tschirgi ML, Ford SJ, Slinker BK, Campbell KB (2007) Interaction between myosin heavy chain and troponin isoforms modulate cardiac myofiber contractile dynamics. Am J Physiol Regul Integr Comp Physiol 293:R1595-R1607

68. Dillmann W (2009) Cardiac hypertrophy and thyroid hormone signaling. Heart Fail Rev 15:125-132

69. Khait L, Birla RK (2009) Changes in gene expression during the formation of bioengineered heart muscle. Artif Organs 33:3-15

70. Auman HJ, Coleman H, Riley HE, Olale F, Tsai HJ, Yelon D (2007) Functional modulation of cardiac form through regionally confined cell shape changes. PLoS Biol 5:e53

71. Taneda Y, Konno S, Makino S, Morioka M, Fukuda K, Imai Y, Kudo A, Kawakami A (2010) Epigenetic control of cardiomyocyte production in response to a stress during the medaka heart development. Dev Biol 340:30-40

72. Warkman AS, Whitman SA, Miller MK, Garriock RJ, Schwach CM, Gregorio CC, Krieg PA (2012) Developmental expression and cardiac transcriptional regulation of myh7b (myh14), a third myosin heavy chain in the vertebrate heart. Cytoskeleton (Hoboken) 69(5):324-335

73. van Rooij E, Quiat D, Johnson BA, Sutherland LB, Qi X, Richardson JA, Kelm RJ Jr, Olson EN (2009) A family of microRNAs encoded by myosin genes governs myosin expression and muscle performance. Dev Cell 17:662-673 
74. Bell ML, Buvoli M, Leinwand LA (2010) Uncoupling of expression of an intronic microRNA and its myosin host gene by exon skipping. Mol Cell Biol 30:1937-1945

75. Machida S, Noda S, Takao A, Nakazawa M, Matsuoka R (2002) Expression of slow skeletal myosin heavy chain 2 gene in Purkinje fiber cells in chick heart. Biol Cell 94:389-399

76. Takeda K, Yu Z-X, Qian S, Chin TK, Adelstein RS, Ferrans VJ (2000) Nonmuscle myosin ii localizes to the $z$-lines and intercalated discs of cardiac muscle and to the $\mathrm{z}$-lines of skeletal muscle. Cell Motil Cytoskelet 46:59-68

77. Lu W, Seeholzer SH, Han M, Arnold AS, Serrano M, Garita B, Philp NJ, Farthing C, Steele P, Chen J, Linask KK (2008) Cellular nonmuscle myosins NMHC-IIA and NMHC-IIB and vertebrate heart looping. Dev Dyn 237:3577-3590

78. Tullio AN, Accili D, Ferrans VJ, Yu Z-X, Takeda K, Grinberg A, Westphal H, Preston YA, Adelstein RS (1997) Nonmuscle myosin ii-b is required for normal development of the mouse heart. Proc Nat Acad Sci 94:12407-12412

79. Ma X, Takeda K, Singh A, Yu ZX, Zerfas P, Blount A, Liu C, Towbin JA, Schneider MD, Adelstein RS, Wei Q (2009) Conditional ablation of nonmuscle myosin ii-b delineates heart defects in adult mice. Circ Res 105:1102-1109

80. Lu S, Horowits R (2008) Role of nonmuscle myosin IIB and $\mathrm{N}$-RAP in cell spreading and myofibril assembly in primary mouse cardiomyocytes. Cell Motil Cytoskelet 65:747-761

81. Miano JM, Cserjesi P, Ligon KL, Periasamy M, Olson EN (1994) Smooth muscle myosin heavy chain exclusively marks the smooth muscle lineage during mouse embryogenesis. Circ Res 75:803-812

82. Zhu L, Vranckx R, Khau Van Kien P, Lalande A, Boisset N, Mathieu F, Wegman M, Glancy L, Gasc JM, Brunotte F, Bruneval P, Wolf JE, Michel JB, Jeunemaitre X (2006) Mutations in myosin heavy chain 11 cause a syndrome associating thoracic aortic aneurysm/aortic dissection and patent ductus arteriosus. Nat Genet 38:343-349

83. Pannu H, Tran-Fadulu V, Papke CL, Scherer S, Liu Y, Presley C, Guo D, Estrera AL, Safi HJ, Brasier AR, Vick GW, Marian AJ, Raman CS, Buja LM, Milewicz DM (2007) Myh11 mutations result in a distinct vascular pathology driven by insulinlike growth factor 1 and angiotensin ii. Hum Mol Genet 16:2453-2462

84. Zhu L, Bonnet D, Boussion M, Vedie B, Sidi D, Jeunemaitre X (2007) Investigation of the myh11 gene in sporadic patients with an isolated persistently patent arterial duct. Cardiol Young 17:666-672

85. Morano I, Chai GX, Baltas LG, Lamounier-Zepter V, Lutsch G, Kott M, Haase H, Bader M (2000) Smooth-muscle contraction without smooth-muscle myosin. Nat Cell Biol 2:371-375

86. Ma X, Jana SS, Conti MA, Kawamoto S, Claycomb WC, Adelstein RS (2010) Ablation of nonmuscle myosin II-b and II-c reveals a role for nonmuscle myosin II in cardiac myocyte karyokinesis. Mol Biol Cell 21:3952-3962

87. Macera MJ, Szabo P, Wadgaonkar R, Siddiqui MAQ, Verma RS (1992) Localization of the gene coding for ventricular myosin regulatory light chain (myl2) to human chromosome 12q23q24.3. Genomics 13:829-831

88. Franco D, Markman MMW, Wagenaar GTM, Ya J, Lamers WH, Moorman AFM (1999) Myosin light chain 2a and 2v identifies the embryonic outflow tract myocardium in the developing rodent heart. Anat Rec 254:135-146

89. O’Brien TX, Lee KJ, Chien KR (1993) Positional specification of ventricular myosin light chain 2 expression in the primitive murine heart tube. Proc Nat Acad Sci 90:5157-5161

90. Goswami S, Qasba P, Ghatpande S, Carleton S, Deshpande AK, Baig M, Siddiqui MA (1994) Differential expression of the myocyte enhancer factor 2 family of transcription factors in development: the cardiac factor bbf- 1 is an early marker for cardiogenesis. Mol Cell Biol 14:5130-5138

91. Ghatpande S, Shafiq S, Siddiqui M (2001) Ventricular myosin light chain-2 gene expression in developing heart of chicken embryos. Biol Res 34:1-6

92. Andersen PS, Havndrup O, Bundgaard H, Moolman-Smook JC, Larsen LA, Mogensen J, Brink PA, Børglum AD, Corfield VA, Kjeldsen K, Vuust J, Christiansen M (2001) Myosin light chain mutations in familial hypertrophic cardiomyopathy: phenotypic presentation and frequency in Danish and South African populations. J Med Genet 38:e43

93. Flavigny J, Richard P, Isnard R, Carrier L, Charron P, Bonne G, Forissier J-F, Desnos M, Dubourg O, Komajda M, Schwartz K, Hainque B (1998) Identification of two novel mutations in the ventricular regulatory myosin light chain gene (MYL2) associated with familial and classical forms of hypertrophic cardiomyopathy. J Mol Med 76:208-214

94. Poetter K, Jiang H, Hassanzadeh S, Master SR, Chang A, Dalakas MC, Rayment I, Sellers JR, Fananapazir L, Epstein ND (1996) Mutations in either the essential or regulatory light chains of myosin are associated with a rare myopathy in human heart and skeletal muscle. Nat Genet 13:63-69

95. Kabaeva ZT, Perrot A, Wolter B, Dietz R, Cardim N, Correia JM, Schulte HD, Aldashev AA, Mirrakhimov MM, Osterziel KJ (2002) Systematic analysis of the regulatory and essential myosin light chain genes: genetic variants and mutations in hypertrophic cardiomyopathy. Eur J Hum Genet 10:741-748

96. Richard P, Charron P, Carrier L, Ledeuil C, Cheav T, Pichereau C, Benaiche A, Isnard R, Dubourg O, Burban M, Gueffet J-P, Millaire A, Desnos M, Schwartz K, Hainque B, Komajda M (2003) Project ftEHF: hypertrophic cardiomyopathy: distribution of disease genes, spectrum of mutations, and implications for a molecular diagnosis strategy. Circulation 107:2227-2232

97. Chen J, Kubalak SW, Minamisawa S, Price RL, Becker KD, Hickey R, Ross J, Chien KR (1998) Selective requirement of myosin light chain $2 \mathrm{v}$ in embryonic heart function. $\mathrm{J}$ Biol Chem 273:1252-1256

98. Fodor WL, Darras B, Seharaseyon J, Falkenthal S, Francke U, Vanin EF (1989) Human ventricular/slow twitch myosin alkali light chain gene characterization, sequence, and chromosomal location. J Biol Chem 264:2143-2149

99. Barton PJ, Cohen A, Robert B, Fiszman MY, Bonhomme F, Guénet JL, Leader DP, Buckingham ME (1985) The myosin alkali light chains of mouse ventricular and slow skeletal muscle are indistinguishable and are encoded by the same gene. J Biol Chem 260:8578-8584

100. Smith SJ, Ataliotis P, Kotecha S, Towers N, Sparrow DB, Mohun TJ (2005) The MLC1v gene provides a transgenic marker of myocardium formation within developing chambers of the Xenopus heart. Dev Dyn 232:1003-1012

101. Shi Q, Danilczyk U, Wang J, See Y, Williams W, Trusler G, Beaulieu R, Rose V, Jackowski G (1991) Expression of ventricular myosin subunits in the atria of children with congenital heart malformations. Circ Res 69:1601-1607

102. Andersen P, Hedley P, Page S, Syrris P, Moolman-Smook J, McKenna W, Elliot P, Christiansen M (2012) A novel myosin essential light chain mutation causes hypertrophic cardiomyopathy with late onset and low expressivity. Biochem Res Int 2012:6

103. Arad M, Penas-Lado M, Monserrat L, Maron BJ, Sherrid M, Ho CY, Barr S, Karim A, Olson TM, Kamisago M, Seidman JG, Seidman CE (2005) Gene mutations in apical hypertrophic cardiomyopathy. Circulation 112:2805-2811

104. Bonne G, Carrier L, Richard P, Hainque B, Schwartz K (1998) Familial hypertrophic cardiomyopathy: from mutations to functional defects. Circ Res 83:580-593 
105. Epstein ND (1998) The molecular biology and pathophysiology of hypertrophic cardiomyopathy due to mutations in the beta myosin heavy chains and the essential and regulatory light chains. Adv Exp Med Biol 453:105-114

106. Lee W-H, Hwang TH, Kimura A, Park SW, Satoh M, Nishi H, Harada H, Toyama J, Park J-E (2001) Different expressivity of a ventricular essential myosin light chain gene Ala57Gly mutation in familial hypertrophic cardiomyopathy. Am Heart $\mathbf{J}$ 141:184-189

107. Olson TM, Karst ML, Whitby FG, Driscoll DJ (2002) Myosin light chain mutation causes autosomal recessive cardiomyopathy with mid-cavitary hypertrophy and restrictive physiology. Circulation 105:2337-2340

108. Price KM, Littler WA, Cummins P (1980) Human atrial and ventricular myosin light chains subunits in the adult and during development. Biochem J 191:571-580

109. Barton PJ, Buckingham ME (1985) The myosin alkali light chain proteins and their genes. Biochem J 231:249-261

110. Chen Z, Huang W, Dahme T, Rottbauer W, Ackerman MJ, Xu $X$ (2008) Depletion of zebrafish essential and regulatory myosin light chains reduces cardiac function through distinct mechanisms. Cardiovasc Res 79:97-108

111. Auckland LM, Lambert SJ, Cummins P (1986) Cardiac myosin light and heavy chain isotypes in tetralogy of Fallot. Cardiovasc Res 20:828-836

112. Schaub MC, Tuchschmid CR, Srihari T, Hirzel HO (1984) Myosin isoenzymes in human hypertrophic hearts. Shift in atrial myosin heavy chains and in ventricular myosin light chains. Eur Heart J 5:85-93

113. Ritter O, Haase H, Schulte HD, Lange PE, Morano I (1999) Remodeling of the hypertrophied human myocardium by cardiac bHLH transcription factors. J Cell Biochem 74:551-561

114. Morano I, Hädicke K, Haase H, Böhm M, Erdmann E, Schaub MC (1997) Changes in essential myosin light chain isoform expression provide a molecular basis for isometric force regulation in the failing human heart. $\mathrm{J}$ Mol Cell Cardiol 29:1177-1187

115. Fewell J, Hewett T, Sanbe A, Klevitsky R, Hayes E, Warshaw D, Maughan D, Robbins J (1998) Functional significance of cardiac myosin essential light chain isoform switching in transgenic mice. J Clin Invest 101:2630-2639

116. Hailstones D, Barton P, Chan-Thomas P, Sasse S, Sutherland C, Hardeman E, Gunning P (1992) Differential regulation of the atrial isoforms of the myosin light chains during striated muscle development. J Biol Chem 267:23295-23300

117. Kubalak SW, Miller-Hance WC, O'Brien TX, Dyson E, Chien KR (1994) Chamber specification of atrial myosin light chain-2 expression precedes septation during murine cardiogenesis. J Biol Chem 269:16961-16970

118. Chambers AE, Logan M, Kotecha S, Towers N, Sparrow D, Mohun TJ (1994) The RSRF/MEF2 protein SL1 regulates cardiac muscle-specific transcription of a myosin light-chain gene in Xenopus embryos. Genes Dev 8:1324-1334

119. Latinkic BV, Cooper B, Smith S, Kotecha S, Towers N, Sparrow D, Mohun TJ (2004) Transcriptional regulation of the cardiacspecific MLC2 gene during Xenopus embryonic development. Development 131:669-679

120. Rottbauer W, Wessels G, Dahme T, Just S, Trano N, Hassel D, Burns CG, Katus HA, Fishman MC (2006) Cardiac myosin light chain-2: a novel essential component of thick-myofilament assembly and contractility of the heart. Circ Res 99:323-331

121. Huang C, Sheikh F, Hollander M, Cai C, Becker D, Chu P-H, Evans S, Chen J (2003) Embryonic atrial function is essential for mouse embryogenesis, cardiac morphogenesis and angiogenesis. Development 130:6111-6119
122. Nishigaki R, Shinohara T, Toda T, Omori A, Ichinose S, Itoh M, Shirayoshi Y, Kurimasa A, Oshimura M (2002) An extra human chromosome 21 reduces mlc-2a expression in chimeric mice and Down syndrome. Biochem Biophys Res Commun 295:112-118

123. Schott JJ, Benson DW, Basson CT, Pease W, Silberbach GM, Moak JP, Maron BJ, Seidman CE, Seidman JG (1998) Congenital heart disease caused by mutations in the transcription factor NKX2-5. Science 281:108-111

124. Garg V, Kathiriya IS, Barnes R, Schluterman MK, King IN, Butler CA, Rothrock CR, Eapen RS, Hirayama-Yamada K, Joo K, Matsuoka R, Cohen JC, Srivastava D (2003) GATA4 mutations cause human congenital heart defects and reveal an interaction with TBX5. Nature 424:443-447

125. Li QY, Newbury-Ecob RA, Terrett JA, Wilson DI, Curtis AR, Yi CH, Gebuhr T, Bullen PJ, Robson SC, Strachan T, Bonnet D, Lyonnet S, Young ID, Raeburn JA, Buckler AJ, Law DJ, Brook JD (1997) Holt-Oram syndrome is caused by mutations in TBX5, a member of the brachyury (T) gene family. NatGenet 15:21-29

126. Basson CT, Bachinsky DR, Lin RC, Levi T, Elkins JA, Soults J, Grayzel D, Kroumpouzou E, Traill TA, Leblanc-Straceski J, Renault B, Kucherlapati R, Seidman JG, Seidman CE (1997) Mutations in human TBX5 (corrected) cause limb and cardiac malformation in Holt-Oram syndrome. Nat Genet 15:30-35

127. Kirk EP, Sunde M, Costa MW, Rankin SA, Wolstein O, Castro ML, Butler TL, Hyun C, Guo G, Otway R, Mackay JP, Waddell LB, Cole AD, Hayward C, Keogh A, Macdonald P, Griffiths L, Fatkin D, Sholler GF, Zorn AM, Feneley MP, Winlaw DS, Harvey RP (2007) Mutations in cardiac t-box factor gene TBX20 are associated with diverse cardiac pathologies, including defects of septation and valvulogenesis and cardiomyopathy. Am J Hum Genet 81:280-291

128. Bruneau BG, Bao ZZ, Tanaka M, Schott JJ, Izumo S, Cepko CL, Seidman JG, Seidman CE (2000) Cardiac expression of the ventricle-specific homeobox gene irx 4 is modulated by Nkx2-5 and dHand. Dev Biol 217:266-277

129. Hiroi Y, Kudoh S, Monzen K, Ikeda Y, Yazaki Y, Nagai R, Komuro I (2001) Tbx5 associates with Nk2-5 and synergistically promotes cardiomyocyte differentiation. Nat Genet 28:276-280

130. Maitra M, Schluterman MK, Nichols HA, Richardson JA, Lo CW, Srivastava D, Garg V (2009) Interaction of Gata4 and Gata6 with Tbx 5 is critical for normal cardiac development. Dev Biol 326:368-377

131. Xin M, Davis CA, Molkentin JD, Lien CL, Duncan SA, Richardson JA, Olson EN (2006) A threshold of GATA4 and GATA6 expression is required for cardiovascular development. Proc Natl Acad Sci USA 103:11189-11194

132. Charron F, Paradis P, Bronchain O, Nemer G, Nemer M (1999) Cooperative interaction between GATA- 4 and GATA- 6 regulates myocardial gene expression. Mol Cell Biol 19:4355-4365

133. Parmacek MS (2007) Myocardin-related transcription factors: critical coactivators regulating cardiovascular development and adaptation. Circ Res 100:633-644

134. Jin D, Ni TT, Hou J, Rellinger E, Zhong TP (2009) Promoter analysis of ventricular myosin heavy chain (vmhc) in zebrafish embryos. Dev Dyn 238:1760-1767

135. Park JS, Kim HS, Kim JD, Seo J, Chung KS, Lee HS, Huh TL, Jo I, Kim YO (2009) Isolation of a ventricle-specific promoter for the zebrafish ventricular myosin heavy chain (vmhc) gene and its regulation by gata factors during embryonic heart development. Dev Dyn 238:1574-1581

136. Molkentin JD, Kalvakolanu DV, Markham BE (1994) Transcription factor GATA-4 regulates cardiac muscle-specific expression of the alpha-myosin heavy-chain gene. Mol Cell Biol 14:4947-4957 
137. Wang C, Cao D, Wang Q, Wang DZ (2011) Synergistic activation of cardiac genes by myocardin and tbx5. PLoS ONE 6:e24242

138. Small EM, Warkman AS, Wang DZ, Sutherland LB, Olson EN, Krieg PA (2005) Myocardin is sufficient and necessary for cardiac gene expression in Xenopus. Development 132:987-997

139. Nakajima Y, Yamagishi T, Ando K, Nakamura H (2002) Significance of bone morphogenetic protein-4 function in the initial myofibrillogenesis of chick cardiogenesis. Dev Biol 245:291-303

140. Bao ZZ, Bruneau BG, Seidman JG, Seidman CE, Cepko CL (1999) Regulation of chamber-specific gene expression in the developing heart by Irx4. Science 283:1161-1164

141. Wada H, Hasegawa K, Morimoto T, Kakita T, Yanazume T, Sasayama S (2000) A p300 protein as a coactivator of GATA-6 in the transcription of the smooth muscle-myosin heavy chain gene. J Biol Chem 275:25330-25335

142. Wang Z, Wang DZ, Pipes GC, Olson EN (2003) Myocardin is a master regulator of smooth muscle gene expression. Proc Natl Acad Sci USA 100:7129-7134

143. Barillot W, Treguer K, Faucheux C, Fedou S, Theze N, Thiebaud P (2008) Induction and modulation of smooth muscle differentiation in Xenopus embryonic cells. Dev Dyn 237:33733386

144. Li HJ, Haque Z, Lu Q, Li L, Karas R, Mendelsohn M (2007) Steroid receptor coactivator 3 is a coactivator for myocardin, the regulator of smooth muscle transcription and differentiation. Proc Natl Acad Sci USA 104:4065-4070

145. Gove C, Walmsley M, Nijjar S, Bertwistle D, Guille M, Partington G, Bomford A, Patient R (1997) Over-expression of GATA-6 in Xenopus embryos blocks differentiation of heart precursors. EMBO J 16:355-368

146. Chan JY, Takeda M, Briggs LE, Graham ML, Lu JT, Horikoshi $\mathrm{N}$, Weinberg EO, Aoki H, Sato N, Chien KR, Kasahara H (2008) Identification of cardiac-specific myosin light chain kinase. Circ Res 102:571-580

147. Liu N, Olson EN (2010) Microrna regulatory networks in cardiovascular development. Dev Cell 18:510-525

148. Cullen BR (2004) Transcription and processing of human microRNA precursors. Mol Cell 16:861-865

149. Davis BN, Hata A (2009) Regulation of microRNA biogenesis: a miriad of mechanisms. Cell Commun Signal 7:18

150. Boettger T, Braun T (2012) A new level of complexity: the role of microRNAs in cardiovascular development. Circ Res 110:1000-1013

151. Ivey KN, Muth A, Arnold J, King FW, Yeh RF, Fish JE, Hsiao EC, Schwartz RJ, Conklin BR, Bernstein HS, Srivastava D (2008) MicroRNA regulation of cell lineages in mouse and human embryonic stem cells. Cell Stem Cell 2:219-229
152. Takaya T, Ono K, Kawamura T, Takanabe R, Kaichi S, Morimoto T, Wada H, Kita T, Shimatsu A, Hasegawa K (2009) MicroRNA-1 and microRNA-133 in spontaneous myocardial differentiation of mouse embryonic stem cells. Circ J 73:14921497

153. Sluijter JP, van Mil A, van Vliet P, Metz CH, Liu J, Doevendans PA, Goumans MJ (2010) MicroRNA-1 and -499 regulate differentiation and proliferation in human-derived cardiomyocyte progenitor cells. Arterioscler Thromb Vasc Biol 30:859-868

154. van Rooij E, Sutherland LB, Qi X, Richardson JA, Hill J, Olson EN (2007) Control of stress-dependent cardiac growth and gene expression by a microRNA. Science 316:575-579

155. Wilson $\mathrm{KD}, \mathrm{Hu} \mathrm{S}$, Venkatasubrahmanyam S, Fu JD, Sun N, Abilez OJ, Baugh JJ, Jia F, Ghosh Z, Li RA, Butte AJ, Wu JC (2010) Dynamic microRNA expression programs during cardiac differentiation of human embryonic stem cells: role for mir- 499 . Circ Cardiovasc Genet 3:426-435

156. Callis TE, Pandya K, Seok HY, Tang RH, Tatsuguchi M, Huang ZP, Chen JF, Deng Z, Gunn B, Shumate J, Willis MS, Selzman $\mathrm{CH}$, Wang DZ (2009) MicroRNA-208a is a regulator of cardiac hypertrophy and conduction in mice. J Clin Invest 119:27722786

157. Cleland JGF, Teerlink JR, Senior R, Nifontov EM, Mc Murray JJV, Lang CC, Tsyrlin VA, Greenberg BH, Mayet J, Francis DP, Shaburishvili T, Monaghan M, Saltzberg M, Neyses L, Wasserman SM, Lee JH, Saikali KG, Clarke CP, Goldman JH, Wolff AA, Malik FI (2011) The effects of the cardiac myosin activator, omecamtiv mecarbil, on cardiac function in systolic heart failure: a double-blind, placebo-controlled, crossover, dose-ranging phase 2 trial. Lancet 378:676-683

158. Yang Y, Gourinath S, Kovacs M, Nyitray L, Reutzel R, Himmel DM, O'Neall-Hennessey E, Reshetnikova L, Szent-Gyorgyi AG, Brown JH, Cohen C (2007) Rigor-like structures from muscle myosins reveal key mechanical elements in the transduction pathways of this allosteric motor. Structure 15:553-564

159. Larkin MA, Blackshields G, Brown NP, Chenna R, McGettigan PA, McWilliam H, Valentin F, Wallace IM, Wilm A, Lopez R, Thompson JD, Gibson TJ, Higgins DG (2007) ClustalW and ClustalX version 2.0. Bioinformatics 23:2947-2948

160. Goujon M, McWilliam H, Li W, Valentin F, Squizzato S, Paern J, Lopez R (2010) A new bioinformatics analysis tools framework at EMBL-EBI. Nucleic Acids Res 38:W695-W699

161. Flashman E, Watkins H, Redwood C (2007) Localization of the binding site of the c-terminal domain of cardiac myosin-binding protein-c on the myosin rod. Biochem J 401:97-102

162. Houmeida A, Holt J, Tskhovrebova L, Trinick J (1995) Studies of the interaction between titin and myosin. J Cell Biol $131: 1471-1481$ 